Revista lus et Praxis, Año 25, No 1, 2019, pp. 481 - 518

ISSN 0717 - 2877

Universidad de Talca - Facultad de Ciencias Jurídicas y Sociales

El juramento en el proceso de arbitraje interno en Chile: reflexiones sobre la entidad de este requisito formal, analizado desde sus fuentes históricas directas

Carlos Andrés Alarcón Machuca

Trabajo recibido el 10 de enero de 2017 y aprobado el 12 de noviembre de 2018

\title{
El juramento en el proceso de arbitraje interno en Chile: reflexiones sobre la entidad de este requisito formal, analizado desde sus fuentes históricas directas
}

\author{
THE OATH IN THE INTERNAL ARBITRATION PROCESS IN CHILE: \\ REFLECTIONS ABOUT THE ENTITY OF THIS FORMAL REQUIREMENT, \\ ANALYZED FROM ITS DIRECT HISTORICAL SOURCES
}

\section{Carlos Andrés Alarcón Machuca*}

\begin{abstract}
RESUMEN
El presente trabajo pretende formular un estudio de los requisitos normativos del proceso de arbitraje interno nacional, sustentado en un análisis a partir de las fuentes que sirvieron de modelos legales a nuestro codificador procesal civil sobre la materia. Al efecto, se propone que los árbitros son una categoría diversa de tribunal, con estatuto legal propio, no siendo posible interpretar los artículos 236 y 240 del Código Orgánico de Tribunales, a la luz de las normas legales que regulan la instalación de los jueces ordinarios estatales. En este sentido, aceptación y juramento son requisitos asimétricos; el primero, requisito de existencia del proceso arbitral, a diferencia del juramento, concebido por el legislador como garantía del adecuado ejercicio de la función del árbitro, función ajena de elementos que afecten su independencia e imparcialidad, siendo este irrelevante para el ejercicio de la función jurisdiccional del árbitro.
\end{abstract}

\section{ABSTRACT}

The present work aims to formulate a study of requirements of national internal arbitration, based on an analysis from the sources that served as legal models to our civil procedural coder on the matter. Therefore, intends that the arbitrator, are a different court category, with their own legal status, not being possible to interpret articles 236 and 240 of the organic code of courts, because of the legal rules governing the installation of regular State judges. In this respect, acceptance and oath are asymmetric requirements; the first requirement of existence of the arbitration process, in contrast to the oath, conceived by the legislator as a guarantee of the suitable exercise of the function of the arbitrator, function without elements that affect their independence and impartiality, being this irrelevant to the exercise of the jurisdictional function of the arbitrator.

\author{
PALABRAs CLAVE \\ Árbitros, Aceptación, Juramento
}

\footnotetext{
* Profesor de Derecho Procesal de la Universidad Católica del Norte (Antofagasta, Chile). Licenciado en Ciencias Jurídicas, Universidad Católica del Norte, Abogado. Correo electrónico: calarcon02@ ucn.cl.
} 
KEY WORDS

Arbitrator, Acceptance, Oath

\section{Aspectos preliminares}

La presente investigación tiene por objeto dilucidar el valor o carácter que tiene el juramento en el proceso arbitral interno, a la luz de la normativa legal que rige en Chile sobre la materia.

El problema se presenta considerando que las normas del Código Orgánico de Tribunales, a propósito del arbitraje, no indican con precisión, a diferencia de lo que ocurre en el caso de los jueces estatales, el cariz de la mencionada exigencia formal, la oportunidad para realizarla, ni menos aún la sanción asociada a la infracción del juramento por parte del árbitro.

En este sentido, el tema señalado es abordado tangencialmente por nuestra jurisprudencia, sin examinar en profundidad el juramento, ni la naturaleza del mismo. Así, fallos del siglo XIX se concentraban en determinar qué sanción procedía ante la falta de juramento por parte del árbitro, entendiendo que la omisión de este constituía un vicio que anulaba la sentencia dictada por el árbitro, debiendo las partes reclamar del señalado vicio necesariamente dentro del juicio arbitral, pues, una vez que el árbitro dictaba sentencia definitiva, el vicio señalado se saneaba ${ }^{1}$. Cabe señalar que otros fallos de la época entendían que el juramento era una garantía para las partes, las que podían exigir el cumplimiento de esa formalidad antes de que terminara el juicio arbitral, pero no se sancionaba con la nulidad del compromiso ${ }^{2}$.

\footnotetext{
1 Ballesteros (1890), p. 123, da cuenta de diversos fallos sobre la materia. En este sentido la Corte de Apelaciones de Concepción respecto de la nulidad de la sentencia pronunciada por un juez árbitro, fundándose en que este no juró el cargo al aceptarlo señala "espresa la sentencia, que el vicio en que se funda el primer capítulo de nulidad, suponiendolo cierto, ocurrió desde el principio del juicio, i no fue reclamado por ninguna de las partes ántes del pronunciamiento de la sentencia; sin cuya circunstancia no puede declararse nulidad, según lo dispuesto en el art. 15 de la lei de $1^{\circ}$ de marzo de 1837; "i por esta razon se declaró sin lugar al recurso de nulidad deducido (Gaceta de 1878 , s. 4568)". Por su parte la Corte de Apelaciones de Talca, frente al no juramento por parte de un árbitro resolvió de forma análoga a la Corte de Apelaciones de Concepción, señalando "Si bien es cierto que en la diligencia de aceptacion no se consignó la forma usual del juramento, de esa omision no reclamaron los herederos, procediendose a verificar todos los actos de la particion". El mismo tratadista señala la opinión de los señores Gundian i Fernandez Carvallo, manifestando un voto especial en la causa, "que estimaban omision del juramento como causal de nulidad; pero, no habiéndose deducido el recurso conforme a la lei, la sentencia debia pasar a autoridad de cosa juzgada, quedando las partes obligadas a su cumplimiento. (Gaceta de 1889, s. 4955)".
}

2 Ballesteros (1890), p. 123, señala: "Se demandó ante el juez de derecho la nulidad del fallo de un compromisario, entre varios capítulos, por no haber aceptado éste el cargo, prévia la solemnidad del juramento. El juez de letras, despues de hacer notar que el art. 183 declara nulo el nombramiento de árbitro únicamente cuando en la escritura se ha omitido la espresion de los puntos $1^{\circ}, 2^{\circ}$ i $3^{\circ}$ de 


\begin{abstract}
El razonamiento antes expuesto empieza a cambiar, dejando de concebir los tribunales superiores de justicia al juramento como una garantía en favor de las partes, entendiéndolo, más bien, como el medio legal de instalación de los árbitros; existiendo un fallo de la Corte de Apelaciones de Santiago del año $1929^{3}$ en dicho sentido. La jurisprudencia ${ }^{4}$, con el pasar de los años, mantuvo el criterio precedentemente expuesto, entendiendo que la infracción del juramento impide que el árbitro ejerza válidamente sus funciones,
\end{abstract}

ese artículo, agrega 'Que, el art. 185, que exije el juramento para la aceptacion del compromisario, no impone pena de nulidad por falta de este requisito como lo hace en el 183 respecto de las circunstancias anteriormente enunciadas; i por consiguiente solo da derecho a las partes para que, como garantía, puedan exijir esa formalidad ántes de que termine el juicio' en consecuencia rechazo la demanda de nulidad". A su vez, el autor da cuenta de otro fallo en el mismo sentido, indicando "en un juicio sobre nulidad de la constitucion de un compromiso, se alegaba entre otros fundamentos que el árbitro no había jurado desempeñar el cargo con la debida fidelidad. El juez rechazo la demanda en esa parte en virtud de estos considerandos: ' $1 .{ }^{\circ}$ que el escribano que tomó al árbitro el juramento que prescribe la Lei, espresa en un certificado que el juramento fué tomado en debida forma; pero que la dilijencia se redactó con omision de la palabra fielmente, por equivocacion que atribuye al escribiente: i $2 .^{\circ}$ que, aun cuando el juramento no hubiese sido tomado en los terminos que la lei exije, la omision de tal formalidad no acarrearia la nulidad del compromiso, puesto que la lei no la precribe como un requisito para el valor del acto o contrato de compromiso, sino como una garantía en favor del derecho de las partes; quienes pueden exijir su cumplimiento, si hubiese sido omitida o indebidamente ejecutada'". A su vez el autor da cuenta de un fallo de la Corte de Apelaciones de Concepción del año 1880 en idéntico sentido.

3 Aytwin (2014), p. 379, nota 814 da cuenta del fallo dictado por la Corte de Apelaciones de Santiago el año 1929, señalando "siendo el juramento el medio legal de instalación de los árbitros como tales, mientras no juren no se pueden considerárseles legalmente instalados, ni pueden, en consecuencia, comenzar a ejercer válidamente sus funciones, pues si así lo hicieran obrarían con manifiesta incompetencia".

${ }^{4}$ Orrego (1985), p. 95, recopila una serie de fallos sobre el asunto. En este sentido la Corte Suprema con fecha 31 de agosto de 1979 señala "los jueces árbitros para desempeñarse en calidad de tales deben aceptar el cargo y jurar desempeñarlo fielmente ante un ministro de fe que deje constancia de la realidad de dicho juramento; dicha formalidad es esencial para la validez de todo procedimiento que se siga ante un árbitro arbitrador.

Por faltar en el caso dado dicha formalidad, se anula de oficio todo lo obrado en autos". Entendiendo que las formalidades del artículo 236 del Código Orgánico de Tribunales son esenciales para la validez del arbitraje. Otro fallo del máximo tribunal, de 23 de octubre de 1964, señala "La omisión del juramento importa la falta de jurisdicción del árbitro, ya que éste no adquiere el carácter de juez mientras no se instale en forma legal". Por lo demás, la Corte Suprema ha entendido que la aceptación y el juramento son requisitos copulativos, resolviendo el año 1959 que "La aceptación expresa y el juramento de rigor del árbitro son complementarios, de modo que sin la concurrencia del juramento, la aceptación es inoperante". Finalmente respecto de la reclamación extemporánea por falta de juramento, la Corte Suprema ha entendido en fallo de 12 de mayo de 1969 que "No prestado por el árbitro dicho juramento, tal vicio pudo motivar una reclamación de las partes ante el árbitro mismo o ante el tribunal competente, pero si no lo hicieron y, por el contrario, acudieron ante el arbitrador y se sometieron a su decisión, una vez conocida la sentencia, el recurso de queja resulta jurídicamente inoportuno, aparte de éticamente no recomendable". 
pues el árbitro, ante la vulneración señalada, no cumple con la forma legal de instalación ${ }^{5}$ actuando con manifiesta incompetencia ${ }^{6}$. Sin perjuicio de lo señalado, entendían que tal infracción, al igual que la jurisprudencia de antaño, se debía reclamar dentro del juicio arbitral, configurándose nulidad procesal; aspecto que en los últimos años ha empezado a cambiar, existiendo un fallo de la Corte de Apelaciones de Concepción que acogió un recurso de protección sobre el punto, entendiendo que cualquier actuación que el árbitro realice sin cumplir con la aceptación y juramento es ilegal, vulnerándose la garantía constitucional relacionada con la prohibición de ser juzgado por comisiones especiales ${ }^{7}$.

\footnotetext{
5 Orrego (1994), t. XCl, No 1 sec. 5a , pp. 15-20, indica un fallo de la Corte Suprema de 25 de abril de 1994, el que sigue idéntica argumentación del fallo de la Corte de Apelaciones de 1929, indicando "Siendo el juramento el medio legal de instalación de los árbitros como tales, mientras no juren no pueden considerárseles legalmente instalados, ni pueden, en consecuencia, comenzar a ejercer válidamente sus funciones pues si lo hicieren obrarían con manifiesta incompetencia".
}

${ }^{6}$ La Corte de Apelaciones de Punta Arenas, rol No 252-13, de 25 de octubre de 2013, a propósito de un recurso de casación en la forma señala "Que de lo que se viene señalando resulta inconcuso que el juramento es un trámite que deben cumplir los árbitros de derecho para asumir su cargo, tal como tiene que hacerlo cualquier juez de la República que se desempeñe en la Justicia Ordinaria para asumir su cargo e instalar el tribunal, de modo que, mientras no se cumpla con dicha exigencia, no puede entenderse legalmente instalado el tribunal y, por ende, el juez no podrá ejercer válidamente sus funciones, pues carecerá de Jurisdicción y consecuentemente, no tendrá competencia para actuar en las causas sometidas a su conocimiento y resolución.

En la especie se ha configurado precisamente ésta situación procesal, por cuanto el señor juez árbitro designado, nunca prestó juramento, ni antes de aceptar el cargo ni después, de modo que es posible sostener que la causa se tramitó ante un tribunal incompetente, según se ha explicado".

7 En este sentido, la Corte de Apelaciones de Concepción, rol № 1713-2014, de 30 de junio de 2014, recurso de protección, dicta sentencia definitiva, acogiendo el recurso de protección intentado por la recurrente. Al respecto, el Tribunal de Alzada entiende, sin perjuicio de que estamos frente a un árbitro arbitrador, de todas formas, existen: "ciertas normas básicas de procedimiento a que deben, necesariamente someterse los árbitros arbitradores, las cuales dicen relación, en primer término con la aceptación del cargo y el juramento de desempeñarlo con la debida fidelidad y en el menor tiempo posible, así como aquellas que dicen relación con el emplazamiento de las partes". Complementa lo anterior indicando que: "en doctrina se ha enseñado tradicionalmente que el nombramiento de árbitro hecho por las partes no basta para hacer surgir el juicio arbitral, ya que ello no obliga a la persona designada a asumir el cargo de compromisario. Para que el arbitraje se verifique es necesario que el árbitro designado acepte cumplir la misión que se le ha encomendado". Vincula lo anterior con el juramento del árbitro señalando que "Ese juramento tiene la misma significación que el juramento de todo Juez, esto es la forma legal de instalación del Tribunal como tal, en consecuencia, mientras no medie juramento del árbitro al tenor de la fórmula dispuesta en el artículo 236 del Código Orgánico de Tribunales, no puede considerársele legalmente instalado, ni puede comenzar a ejercer válidamente las funciones propias del Tribunal Arbitral, en caso contrario obraría con manifiesta incompetencia". En razón de lo señalado concluye que: "el recurrido ha desarrollado una actuación ilegal, desde que no se ha ajustado en su proceder como árbitro a lo que la ley le exige (aceptar el encargo y prestar juramento de rigor de acuerdo al artículo 236 del Código Orgánico de Tribunales). De hecho, no ha podido realizar ninguna gestión como Tribunal Arbitral, desde que no 
Ante lo expuesto, se nos presentan algunas dificultades o problemas jurídicos, particularmente determinar la justificación normativa que sustenta la incompetencia del árbitro ante la falta de juramento, aspecto ampliamente sostenido por la jurisprudencia, o aquel sustento legal y constitucional que permita concluir que la infracción del requisito formal indicado conduciría inexorablemente a la constitución de una comisión especial.

La aridez de los textos legales involucrados torna compleja la solución de las dificultades planteadas, siendo interesante recurrir a un análisis de las fuentes históricas directas vinculadas con el proceso de arbitraje interno, con el juez árbitro, y los requisitos formales de este proceso arbitral, la aceptación y el juramento. Este trabajo, con un enfoque metodológico histórico dogmático, intentará comprender el trabajo del codificador procesal, recabando el verdadero sentido del juramento en el proceso arbitral interno, a la luz de la normativa nacional sobre la materia. Al efecto, nuestro trabajo se sustenta en tres hipótesis: En primer término, nuestra investigación afirma que los árbitros en Chile son una categoría especialísima de tribunal, distinta a los jueces estatales, siendo equiparados con estos últimos, legislativamente, sólo desde la perspectiva funcional. En segundo lugar, nuestra investigación afirma que el juramento que realiza el árbitro en el proceso arbitral interno en Chile es una garantía que este presta a las partes, de desempeñar correctamente su función, ajena a cualquier elemento que pueda afectar su independencia e imparcialidad. En tercer término, nuestra investigación afirma que la infracción del juramento que realiza el árbitro en el proceso arbitral interno en Chile, no provoca la incompetencia del tribunal arbitral ni configura una comisión especial. El objetivo general de este trabajo es describir y explicar el juramento que realiza el árbitro en el proceso arbitral interno en Chile, con el objeto de resolver las incidencias que provoca su infracción en dicho proceso. Por su parte, podemos señalar como objetivos específicos de este trabajo: 1. Describir la evolución histórico-normativa del tribunal arbitral en el proceso arbitral interno en Chile. 2. Describir la evolución histórico-normativa del juramento en el proceso arbitral interno en Chile. 3. Determinar de qué forma la infracción del juramento incide en el proceso arbitral interno en Chile.

se ha instalado como tal con arreglo a la ley". Finalmente, en el considerando octavo de la sentencia indica "Que, de lo anterior fluye que la actuación, por demás ilegal del recurrido, ha vulnerado la garantía constitucional contemplada en el artículo $19 \mathrm{~N}^{\circ} 3$ inciso $5^{\circ}$ de la Constitución Política del Estado, desde que se ha erigido en una comisión especial que ha resuelto una aparente controversia entre partes, sin estar legalmente instalado como Tribunal Arbitral...". 


\section{Estudio preliminar de las fuentes que tuvo a la vista el codificador al momento de regular el arbitraje en nuestra legislación}

\subsection{Legislación castellana y textos forenses}

Si pretendemos estudiar las fuentes que el codificador procesal civil tuvo a la vista al momento de recoger el arbitraje interno en nuestra legislación nacional, debemos partir por la legislación castellana precodificación procesal civil, recurriendo en primer término a las Partidas ${ }^{8}$. En este contexto, la partida tercera, título 4, que regula a los jueces, en su ley primera, distingue entre tres categorías de jueces: los jueces ordinarios, que son aquellos que realizan sus oficios sobre aquellos que han de juzgar, cada uno en los lugares que tienen; los jueces delegados, que son aquellos que pueden juzgar según lo mandan los Reyes, los Adelantados o los jueces ordinarios y, por último, los jueces árbitros, que son los escogidos para librar algún pleito señalado por las partes; ${ }^{9}$ regulándose desde la Ley $N^{\circ} 23$ en adelante, del titulo señalado, a los jueces de avenencia, término equivalente a la expresión en latín "árbitros". La Ley $\mathrm{N}^{\circ} 23$ distingue entre aquellos que resuelven los pleitos según derecho, denominados árbitros, quienes deben seguir el pleito de igual manera que un juez ordinario ${ }^{10}$, y los arbitradores, los que son escogidos por avenencia entre las partes para resolver las controversias entre sí, de cualquier manera que estas tuviesen por bien, no estando obligados a guardar las formalidades que los otros jueces deben guardar.

Cabe señalar que la Ley $N^{\circ} 29$ establece que los jueces de avenencia sin ningún apremio pueden recibir los pleitos, pudiendo escoger no tomar ese oficio si no quisieren. Pero si estos optan por recibirlo, y existe negativa o desidia referente a la dictación de la sentencia, las partidas contemplan la posibilidad de que los jueces ordinarios los puedan apremiar, incluso encerrándolos en una casa, privándolos de alimentos, hasta que librasen el pleito ${ }^{11}$. En este sentido, las partidas requieren una manifestación de voluntad por parte

\footnotetext{
${ }^{8}$ Alfonso XI (1847), pp. III-VI. Da cuenta de que las partidas nacen con el propósito de unificar la legislación castellana en un solo cuerpo normativo aplicable a todas las ciudades y villas del reino, ante la proliferación de fueros municipales que regían en cada uno de dichos lugares, textos que tenían carencias relevantes, pues no trataban diversos asuntos fundamentales, aun los más obvios que se planteaban ante los tribunales.

9 Alonso el IX (1844), pp. 81-82.

10 Alonso el IX (1844), pp. 107-108.

11 Alonso el IX (1844), pp. 120-121.
} 
del juez mencionado ${ }^{12}$, siendo necesario que acepte resolver el pleito; sólo a partir de ese momento el árbitro estará obligado a resolver el conflicto, pudiendo ser apremiado por la justicia ordinaria si no lo hiciera. Por último, las partidas no señalan referencia alguna al juramento del árbitro. Por otra parte, recurriendo a otro texto castellano, la Novísima Recopilación, en particular Libro XI, título XVII, ley IV, hace referencia a la ejecución de las sentencias arbitrarias. Al efecto, el texto, remitiéndose a Don Fernando y Doña Isabel en las Ordenanzas de Madrid de 1502 y a doña Juana en Toledo en 1539, sigue utilizando la expresión "jueces", distinguiendo entre los jueces árbitros juris, que son los que determinan conforme a derecho, y los jueces amigos, denominados igualmente como jueces árbitros arbitradores, dejándose de lado la expresión juez avenidor que se empleaba en las partidas ${ }^{13}$. Por su parte, el ordenamiento de Alcalá de Henares ${ }^{14} y$ las Leyes de Toro ${ }^{15}$, textos que se tuvieron a la vista, nada señalan respecto de nuestro tema en estudio.

En este contexto, debemos tener presente que la vasta legislación casteIlana ${ }^{16}$ existente y potencialmente aplicable en nuestro país no regulaba de forma integral diversas materias, lo que tornaba compleja la aplicación de diversas instituciones por parte de jueces y abogados en nuestro país, más aun considerando las carencias en el proceso formativo de los abogados nacionales en la Universidad, cuyos estudios estaban enfocados en derecho romano y derecho canónico ${ }^{17}$. Para salvar, en parte, estas carencias en el proceso de

\footnotetext{
12 EsCRICHE (1852), p. 207, da cuenta de que la aceptación del árbitro podía ser expresa o tácita, recurriendo a lo señalado en la propia Ley No 29 y la opinión de Acevedo en la Novísima Recopilación.

13 LÜвbert (1805), p. 216.

14 Sobre la materia ver Alfonso XI (1847).

15 Sobre este punto, mayores antecedentes en De Llamas (1852), pp. 1-602.

16 Sobre este tema ver LIRA (1895), pp. 10-14.

17 Como señala González (1954), p. 165, "Ha ya quedado de manifiesto en las páginas anteriores que el estudio de las aulas universitarias y, cuando lo hubo, el que se hacía en el Real Colegio San Carlos, comprendía solamente el derecho romano y el canónico, en sus más importantes colecciones. Quedando por tanto, en la preparación profesional de los abogados un doble vacío: por una parte, se omitía el estudio del derecho propiamente español, o real, y por otra, el de la legislación procesal, o leyes prácticas, según entonces se decía". Por su parte Guzmán (2005-2006), p. 361 señala "a) Ya ha quedado dicho que en la Real Universidad de San Felipe, conforme con el modelo seguido en las universidades españolas y europeas en general, sólo eran temas de enseñanza el Derecho Romano y el Canónico, lo cual implicaba la exclusión de los Derechos propios, vale decir, de las Leyes reales. En el caso de una sección de la Corona de Castilla, como era Chile (y el resto de la América española), eso conducía a dejar fuera cuerpos legislativos como las Siete Partidas, el Fuero Real, la Recopilación de las leyes de Castilla ('Nueva Recopilación'), de 1567, y la Novísima Recopilación de leyes de España, de 1805, lo mismo que la Recopilación de las leyes de los reinos de las Indias, de 1680".
} 
formación señalado, se recurría a la literatura jurídica procesal ${ }^{18}$, fuentes cuyo análisis no podemos excluir. Al efecto podemos mencionar, en primer término, a la Curia Philipica de Juan de Hevia Bolaños ${ }^{19}$, aparecida por primera vez en el año 1603. El texto distingue entre la jurisdicción ordinaria, propia de los tribunales ordinarios, y la delegada, vinculada a tribunales especiales ${ }^{20}$. En cuanto a los jueces árbitros, De Hevia no los incluye expresamente en alguna de estas categorías, los considera un órgano distinto. Al respecto trata de forma detallada el compromiso ${ }^{21}$, para luego indicar que los árbitros, a diferencia de los jueces delegados, no pueden ser compelidos a serlo, si no es después de aceptado el compromiso, no debiendo prestar juramento ${ }^{22}$. Finalmente, mantiene la misma distinción entre árbitros de derecho ${ }^{23}$ y arbitradores, indicada en los textos castellanos. Por su parte, Febrero Novísimo de Eugenio de Tapia, trata de forma exhaustiva el tema, reiterando la distinción entre jueces ordinarios, delegados y árbitros ${ }^{24}$, distinguiendo estos últimos entre árbitros de derecho y arbitradores ${ }^{25}$, manteniendo una línea similar a las partidas. Respecto de la obligación de los árbitros de resolver el asunto, al igual que las partidas, establece que no es posible obligarlos antes de la aceptación, sino después ${ }^{26}$, para luego aludir al juramento, entiende que los jueces árbitros deben jurar antes de aceptar el encargo o a lo menos antes de dictar la sentencia, de que ni por odio, enemistad, amor, temor, dádivas, promesas ni otra causa, dejarán de cumplir fielmente su oficio según su inteligencia, dando cuenta que así se practica ${ }^{27}$.

18 Sobre este tema ver González (1954), pp. 171-172.

19 Doucnac (2014), p. 29, da cuenta de que Juan de Hevia y Bolaños, es uno de los más grandes y citados procesalistas indianos.

${ }^{20}$ De HeVIA (1790), p. 19. Tales como los jueces de comisión, a los vicarios foráneos y particulares de los pueblos o partidos, en el derecho canónico.

21 De HeVIA (1790), p. 432.

22 De Hevia (1790), p. 434.

${ }^{23}$ Traduce la expresión "árbitros juris" utilizada en las Ordenanzas de Madrid de 1502 y de Toledo de 1539.

${ }^{24}$ De Tapia (1828), p. 19.

25 De TAPIA (1828), p. 34.

${ }^{26}$ DE TAPIA (1828), p. 35. Señala al respecto que luego de la aceptación del árbitro es posible que el juez ordinario lo pueda compeler a aquello, incluso pudiendo nombrar a un tercero para la resolución del negocio, reiterando el autor las razones señaladas en las partidas, por las cuales no se puede apremiar al árbitro, pese a que se haya verificado la aceptación.

27 De TAPIA (1828), p. 35. 
De la legislación castellana examinada, así como de los textos forenses citados, se desprende que el árbitro es considerado una categoría de juez o tribunal, al igual que el juez ordinario y el juez delegado, pero con características especiales, rasgos propios que lo diferencian de los demás. Lo anterior se aprecia desde la perspectiva del origen y marco en el cual se puede desenvolver el árbitro, pues las partes, y no la ley, son quienes nombran al juez árbitro, determinan la esfera de competencia en la resolución del asunto ${ }^{28}$, así como la forma en que estos proceden. Por otra parte, considerando que es una categoría diversa al juez ordinario, no es posible obligarlo a resolver el conflicto, salvo que medie aceptación, pudiendo incluso excusarse de resolver verificándose las causales que contempla el legislador ${ }^{29}$, distintas a las de un juez ordinario, dadas las especiales características de la figura. Una vez aceptado el encargo, se aprecian claros rasgos jurisdiccionales en el ejercicio de la función ${ }^{30}$, la que se desarrolla en un procedimiento previamente establecido, equiparable en mayor o menor medida con el procedimiento realizado ante un juez ordinario, resolviendo el conflicto de relevancia jurídica mediante una sentencia definitiva, la que no sólo se equipara a la que dicta el juez estatal en cuanto a sus efectos, sino que también, desde la perspectiva recursiva ${ }^{31}$. A su vez, a partir de la mencionada aceptación se ve restringida

\footnotetext{
${ }^{28}$ Las partidas fijan con precisión la competencia de los jueces de avenencia, pues estos no pueden oír a las partes, ni librar los pleitos más allá de la materia o asunto indicado por las partes, debiendo actuar de la manera que las partes determinaren. En este sentido AlOnSO EL IX (1844), pp. 109-110.
}

${ }^{29}$ Alonso el IX (1844), p. 123, la ley 30 contempla las razones por las cuales los jueces de avenencia no pueden ser apremiado para librar dichos pleitos, razones bastante similares a las causales por las cuales cesa la obligación de desempeñar el arbitraje, señaladas en el artículo 240 de nuestro actual Código Orgánico de Tribunales.

30 Los rasgos jurisdiccionales de la función del árbitro, mas no del origen, se denotan incluso en el evento en que las partes pretendan reclamar la nulidad ante el pronunciamiento del árbitro respecto de materias no reguladas en el compromiso, pues la reclamación de nulidad señalada debe formularse en el juicio, en el plazo para recurrir en contra del Laudo, ante el juez ordinario, estando vedada la posibilidad de reclamar fuera del procedimiento. En este sentido en AlonSO EL IX (1844), p. 110, la nota (129) da cuenta de que la nulidad señalada en el caso de los árbitros de derecho en las Partidas está sujeta a la reclamación expresa de las partes dentro del plazo para deducir recursos, es decir 10 días, en caso contrario la sentencia arbitral se entenderá consentida. Respecto del amigable componedor entiende que no se aplica lo señalado, no obstante, entiende que el silencio de las partes una vez publicado el Laudo importa una tácita aquiescencia.

31 En las Partidas la sentencia se puede enmendar según el albedrío de algunos buenos hombres escogidos por el juez ordinario del lugar, excluyendo la Ley No 35 la posibilidad de recurrir de alzada en contra de la sentencia dictada por los jueces avenidores, sin perjuicio de lo cual, después de publicada la ley de Madrid y las nuevas ordenanzas de las Cortes de Toledo del año 1539 se declaró que era procedente el recurso de apelación en contra de las sentencias arbitrales. En este sentido Alonso el IX (1844), p. 129. Ver nota (209). 
la autonomía de la voluntad de las partes, ejerciendo el árbitro la función jurisdiccional, concluyendo dicha labor dictando una sentencia definitiva que resuelve la disputa; opción legislativa ${ }^{32}$ que evoluciona desde la imposibilidad de ejecutar la sentencia dictada por el árbitro ${ }^{33}$, requiriéndose la fijación de una pena en el compromiso para intentar resguardar el cumplimiento de la sentencia; hasta una mayor equiparación funcional con los jueces ordinarios, permitiendo el cumplimiento del fallo, incluso existiendo recursos pendientes en contra de la sentencia, rindiendo caución ${ }^{34}$.

\subsection{Recepción del arbitraje en el derecho patrio}

Cabe señalar que la legislación Castellana antes señalada, así como la literatura jurídica procesal, se aplican e influyen en Chile, incluso luego de la independencia de la República, pues se carecía de normas legales nacionales que trataren de forma integral el arbitraje, sin perjuicio de algunos antecedentes preliminares plasmados en textos constitucionales ${ }^{35}$ y legales previos al proceso de codificación, que aluden al tema ${ }^{36}$. En este sentido, las fuentes mencionadas influyen en el proceso de codificación procesal nacional, siendo los modelos legales que tuvo a la vista el codificador al momento de la recepción del arbitraje en derecho patrio. Al efecto, es interesante examinar el proyecto de ley de organización y atribuciones de los tribunales redactado por Francisco Vargas Fontecilla, del año 1864, texto que regula los tribunales, en términos generales, así como los jueces árbitros, en particular. En este sentido, el proyecto trata a los tribunales en el artículo quinto ${ }^{37}$, para luego

\footnotetext{
32 Alonso el IX (1844), p. 110. Ver nota (131).

33 Las Partidas requiere que las partes estipulen una pena, sin la cual no están obligadas a cumplir con lo resuelto en el Laudo, no existiendo la posibilidad de exigir la ejecución de la sentencia.

${ }^{34}$ En este sentido la Novísima Recopilación da cuenta de que la parte que obtuvo una sentencia favorable puede pedir al Juez la ejecución de la sentencia, debiendo presentar ante aquel el compromiso y la sentencia arbitral. A su vez, la parte que pide la ejecución del fallo debe rendir fianza ante mismo juez que solicita la ejecución de la sentencia señalada. Al respecto ver LüBBERT (1805), p. 217.

35 Sobre el tema ver Jequier (2015), pp. 215-219.

36 Doucnac (2014), p. 48. Así, por ejemplo, podemos mencionar, dentro de algunos de los textos legales que tangencialmente tratan el arbitraje, a las leyes marianas, de 8 de febrero 1837, sobre juicio ejecutivo, normas que confirman la disposición de la Novísima Recopilación, que daba fuerza ejecutiva a las sentencias y laudos de los árbitros, pasados en autoridad de cosa juzgada.

37 VARGAS (1864), pp. 3-4. "a las autoridades que establece la presente lei estará sujeto el conocimiento de todos los asuntos judiciales que se promuevan dentro del territorio de la republica, cualquiera
} 
mencionar los tribunales arbitrales en el artículo sexto ${ }^{38}$. De las normas señaladas, podemos reconocer que Vargas Fontecilla concibió dos categorías diversas de tribunales, los tribunales ordinarios, que conocen la generalidad de los asuntos por disposición de la ley, a los cuales alude en los artículos segundo y quinto del proyecto, y los tribunales arbitrales, a los que alude en el artículo sexto, teniendo una regulación especial y detallada en el título XIII del mencionado proyecto, al igual que las Partidas. En este sentido, del análisis del artículo $213^{39}$, contemplado en el título mencionado, se desprende que para el autor referido, los jueces árbitros son una categoría de tribunal ${ }^{40}$, que ejercen jurisdicción, siendo la fuente del arbitraje el compromiso, distinguiendo entre aquellos jueces denominados árbitros, que deben dictar su fallo sujetándose estrictamente a las leyes, y aquellos árbitros que dictan sentencia sin sujetarse a la exigencia señalada, obedeciendo a lo que su prudencia y equidad le dictaren, empleando el autor la denominación arbitrador o amigable componedor ${ }^{41}$, todo lo cual se enmarca dentro de las ideas plasmadas en las fuentes castellanas y forenses ya referidas. Respecto de la aceptación y el juramento, el artículo 224 alude al punto, señalando que, verificado el nombramiento, se hará saber al árbitro o árbitros nombrados, que acepten el cargo si lo tienen por conveniente. Por su parte el inciso segundo, del mismo

que sea su naturaleza o calidad de las personas que litiguen, quedando en consecuencia abolido todo fuero especial o privilejiado, con las solas excepciones siguientes...".

${ }^{38}$ VARGAS (1864), p. 4, indica que "No obstante lo dispuesto en el artículo anterior, las partes podrán, cuando lo tuvieren a bien, someter de común acuerdo a la resolucion de jueces árbitros las contiendas que entre ellas se susciten, procediendo en tal caso con arreglo a lo prevenido en el título XIII de esta lei".

${ }^{39}$ VARGAS (1864), p. 66, indica el artículo 213 del proyecto que "Se llaman árbitros los jueces nombrados por las partes, o por la autoridad pública en subsidio, para la resolución de un asunto litijioso.

El árbitro legalmente nombrado queda revestido de la facultad de administrar justicia en el negocio sometido a su conocimiento.

La jurisdiccion del árbitro tiene por fuente la voluntad de las partes o sea la convención celebrada por ellas al hacer el nombramiento.

Esta convención se llama compromiso".

40 Doucnac (2014), pp. 46-47, da cuenta de la disputa entre el poder ejecutivo y el judicial, referente a quien puede autorizar a los Ministros de Corte para ejercer funciones como compromisario. La Corte Suprema entendía que era su prerrogativa, en virtud de la Superintendencia directiva, correccional y económica que tiene respecto de todos los tribunales de la nación, lo que, a su vez, se sustentaba en el artículo 148 de la Constitución de 1823. En este contexto podemos estimar que, para el máximo tribunal, los jueces árbitros eran una categoría de tribunal, incluso antes del propio proceso de codificación.

${ }^{41}$ VARGAS (1864), p. 66. 
artículo, exige que el juramento se verifique al tiempo de la aceptación, debiendo jurar desempeñar su cargo con toda fidelidad y en el menor tiempo posible ${ }^{42}$. Vinculado con la disposición señalada, el artículo 233 indica que los árbitros, una vez aceptado su cargo, quedan obligados a desempeñarlo, estableciendo las causales de cese de tal obligación ${ }^{43}$, idénticas a las actualmente vigentes.

Sin perjuicio de la claridad del texto de Vargas Fontecilla sobre la materia, el proyecto fue objeto de revisión por orden del Presidente de la República, José Joaquín Pérez, conformándose una comisión revisora, que modificó alguna de las disposiciones señaladas, siendo estas más similares a las que aparecen en el texto definitivo de la ley de organización y atribuciones de los tribunales, así como al Código Orgánico de Tribunales actualmente vigente. En este sentido, el texto, parcialmente revisado por la Comisión, es publicado el año 1872, modificándose el artículo $5^{\circ}$ inciso primero del proyecto ${ }^{44}$, precisando la Comisión la noción primitiva de Vargas Fontecilla, cambiando la expresión "autoridades" por "tribunales"; conservando el sentido original de la norma, es decir, el reconocimiento y conceptualización de los tribunales ordinarios de justicia, categoría concebida en idénticos términos que las Partidas. Por su parte, el artículo $6^{\circ}$ del proyecto original, que aludía a los jueces árbitros, es suprimido, desapareciendo del proyecto publicado por la Comisión Revisora el año 1872, y, en definitiva, de la ley. Las razones para suprimir la disposición señalada, están vinculadas a la forma de redacción del artículo quinto del proyecto modificado, sin alterar la concepción de los árbitros como una categoría diversa de tribunal. Así, la norma indicaba "a los tribunales que establece la presente lei...", no siendo posible, ante tal redacción, considerar a los jueces árbitros como un tribunal de excepción, pues el nombramiento y las funciones de este tribunal están determinados por la ley ${ }^{45}$. Por lo demás, la redacción del inciso primero del citado artículo,

\footnotetext{
42 VARGAS (1864), p. 69.

${ }^{43}$ VARGAS (1864), p. 72.

${ }^{44}$ Orrego (1872), p. 6. señala en el artículo $5^{\circ}$ inciso primero que "A los tribunales que establece la presente lei estará sujeto el conocimiento de todos los asuntos judiciales que se promuevan dentro del territorio de la República, cualquiera que sea su naturaleza o la calidad de las personas que en ellos intervengan, con las solas escepciones siguientes: ...".

45 Ballesteros (1890), p. 72, señala "Alterada por la Comision Revisora la base del primer título de la lei, no llegó a ser tomado en cuenta el art. 6 del proyecto, que sin duda habria sido desechado; puesto que no puede ser considerado como tribunal de escepcion el juez árbitro, cuyo nombramiento i funciones están determinadas por esta lei. Por lo demas, las disposicion habría sido en todo caso redundante i sin objeto especial".
} 
intenta conceptualizar a los jueces ordinarios, como aquellos que conocen la generalidad de los asuntos judiciales que se promuevan dentro del territorio de la República, siendo incompatible dicha noción con la categoría de tribunales arbitrales, quienes intervienen en un asunto específico, delimitando las partes, de común acuerdo, su competencia.

El proyecto publicado por la Comisión Revisora el año 1872, regulaba en un título diverso, el título XI, a los jueces árbitros. Este proyecto, cuya redacción es igual al texto definitivo de la ley, modifica drásticamente el artículo $213^{46}$ del proyecto original ${ }^{47}$, cambios que se justifican nuevamente en aspectos formales, y no con una modificación radical en la concepción de los jueces árbitros. Así, el inciso tercero del artículo 213 del proyecto original, que señalaba "La jurisdiccion del árbitro tiene por fuente la voluntad de las partes o sea la convención celebrada por ellas al hacer el nombramiento"48, se suprimió, no porque los miembros de la Comisión Revisora pensaran que el juez árbitro no ejerciera jurisdicción, estando al parecer convencidos de lo contrario ${ }^{49}$, sino que cuestionaban lo inexacto del texto, debido a que la jurisdicción del árbitro no siempre tiene su origen en la voluntad de las partes, sino que también en la misma ley. Por otra parte, el inciso segundo del artículo señalado, indicaba que "El árbitro legalmente nombrado queda revestido de la facultad de administrar justicia en el negocio sometido a su conocimiento $^{\prime \prime 50}$ fue suprimido por la Comisión Revisora, debido a que tal

\footnotetext{
${ }^{46}$ El artículo señalado pasa a ser el artículo 172 del proyecto revisado por la Comisión, así como de la ley de organización y atribuciones de los tribunales.

47 Ballesteros (1890), pp. 72-73. La comisión modifica el articulado del proyecto original, pasando el artículo 213 del proyecto de Vargas Fontecilla, al 172 del proyecto revisado por la comisión, numeración que mantiene en la ley de Organización y atribuciones de los tribunales. En este sentido, el artículo 172 señalado indicaba "Se llaman árbitros los jueces nombrados por las partes, o por la autoridad judicial en subsidio, para la resolución de un asunto litigioso".

48 VARGAS (1864), p. 66.

49 Ballesteros (1890), p. 73, indica que "1606.- El arbitraje o compromiso es una de las jurisdicciones primitivas, i tan conforme al derecho natural que ella ha sido adoptada en todas partes desde la mas remota antigüedad". Complementando el tema el autor indica en p. 74 que "1609.- A pesar de esta controversia, la verdad es que el arbitraje ha sido jeneralmente reconocido como un medio pacifico, pronto, sencillo i económico de determinar las contiendas que surjen entre los particulares, i evitar las consecuencias de un procedimiento judicial, remedio que ha adoptado nuestra Lei siguiendo las antiguas instituciones de España (...) 1610.- Nuestra Lei ha hecho del arbitraje una jurisdiccion, i en tal carácter sus sentencias deben ser obedecidas por las partes comprometidas como si ellas emanasen de los jueces ordinarios. Ha cambiado pues radicalmente la base de la institucion, i en tal concepto, era inútil mantener la disposicion romana que hacia al compromiso una obligacion con cláusula penal".

${ }^{50}$ VARGAS (1864), p. 66.
} 
redacción era innecesaria y demasiado clara. Finalmente, el inciso cuarto fue suprimido por razones similares a las esgrimidas respecto del inciso tercero $^{51}$. Por otra parte, el artículo 146 del proyecto publicado por la Comisión Revisora, al conceptualizar al juez árbitro, innova utilizando la denominación "árbitro de derecho", expresión plasmada en textos legales castellanos posteriores a las Partidas, "árbitros juris", así como en la literatura jurídica procesal previamente citada ${ }^{52}$. Respecto de la aceptación y el juramento, la Comisión Revisora cambia aspectos formales del texto, manteniendo la esencia del proyecto original, salvo la exigencia relacionada con el momento en que se debe jurar por parte del árbitro. Así la norma aprobada, artículo $185^{53}$, queda en idénticos términos a nuestro actual artículo 236 del Código Orgánico de Tribunales $s^{54}$.

De lo expresado podemos concluir, de conformidad a las fuentes examinadas, que los árbitros son considerados como una categoría de juez, con diferencias marcadas respecto de los jueces ordinarios. En este sentido, nuestro legislador opta por una equiparación sólo funcional respecto de los jueces ordinarios, particularmente los árbitros de derecho, careciendo de una equiparación orgánica respecto de tales tribunales, apreciándose fuertemente la influencia de las fuentes examinadas.

\section{Los árbitros como categoría de tribunal en nuestra legislación interna}

El estudio orgánico de los árbitros, en particular determinar si son jueces o una entidad distinta, ha sido marcado por la discusión vinculada a determinar

\footnotetext{
51 Ballesteros (1890), p. 73, dando cuenta del debate en la Comisión Revisora indica que "En debate, dice el acta, el art. 213, a que corresponde el núm. 139 (172) se suprimió, a indicacion del señor Blest Gana, el inciso tercero por inexacto, pues no siempre la jurisdiccion arbitral tiene su orijen en la voluntad de las partes, desde que la misma Lei establece ciertos casos de compromiso forzado. Se suprimieron tambien, a solicitud del señor Campillo, el inciso cuarto por estar basado en el tercero i adolcer de la misma inexactitud; i el segundo por ser innecesario i demasiada clara su disposicion. Se acordó igualmente, a peticion del señor Campillo, decir autoridad judicial en vez de autoridad pública en el inciso primero, para hacer mas exacta i determinada la disposicion".

52 Orrego (1872), p. 43.

53 Ballesteros (1890), p. 121. Artículo 185 del proyecto de la comisión revisora señala "El árbitro que acepta el encargo deberá declararlo así, i jurará desempeñarlo con la debida fidelidad i en el menor tiempo posible".

${ }^{54}$ Ballesteros (1890), p. 121. Al respecto, el señor Lira, miembro de la comisión revisora, criticaba el artículo 224 del proyecto original, pues parecía redactado como una disposición de procedimiento, siendo conveniente dar una forma más adecuada a la ley de organización y atribuciones de los tribunales, proponiendo el señor Huneeus, otro miembro de la comisión, emplear los términos señalados en el artículo 1328 del Código Civil, a propósito de la partición, quedando la norma con dicha redacción.
} 
la naturaleza jurídica del arbitraje. En este sentido, quienes defienden la noción jurisdiccional del arbitraje, sustentan que los árbitros son tribunales de justicia, existiendo dentro de este grupo opiniones divergentes, entre los que conciben a los árbitros como jueces que forman parte del aparato estatal y otros que los consideran jueces privados que ejercen la función jurisdiccional. Desde la otra vereda surgen opiniones que rechazan que los árbitros sean un tribunal que ejerza una función jurisdiccional. Así, tradicionalmente en nuestro país se ha sostenido por la dogmática nacional que los árbitros son un tribunal. En esta línea de pensamiento podemos recurrir a Aylwin Azócar ${ }^{55}$, quien sostiene que los árbitros son jueces, entendiendo que uno de los rasgos del juicio arbitral es la naturaleza extraordinaria del tribunal Ilamado a sentenciar, ejerciendo jurisdicción. Recalca que no se trata de un tribunal constituido permanentemente, sino que es preciso darle vida para cada caso, por las partes, el juez o difunto, según corresponda ${ }^{56}$. En esta misma línea de pensamiento podemos incluir a Abeliuk ${ }^{57}$, Casarino, Orellana ${ }^{58}$, Figueroa y Morgado ${ }^{59}$. Por otra parte, Silva Bascuñán considera a los jueces árbitros no sólo como tribunales especiales de la nación ${ }^{60}$, sino como órganos del

\footnotetext{
55 AyLWIN (2014), p. 15, cita a un destacado autor uruguayo, don Julián Miranda, indicando que el árbitro es un "tribunal facultado para resolver esa disputa mediante una decisión obligatoria para las partes. No otra cosa son los árbitros". A su vez, en p.156 citando a Glasson, Tissier y Morel indica que los árbitros "son personas escogidas por las partes para juzgar un litigio. Allí donde no hay litigio, o donde la persona escogida para ocuparse de él no está encargada de resolverlo, no hay arbitraje ni árbitros".
}

56 AYLWIN (2014), p. 156.

57 Aвelıuk (2014), p. 22, indica "El árbitro es un juez, y en consecuencia, debe ejercer como tal, pero en su caso hay una diferencia fundamental con los demás jueces: no es un funcionario que esté inserto en el escalafón, ni hace carrera ni se remunera por el Estado, salvo casos excepcionales en que la ley así lo establezca, y su relación es meramente ocasional".

${ }^{58}$ También podemos sumar dentro de los autores que consideran al árbitro como juez a CASARINO (2006), p. 11, indicando "al estudiar los diversos tribunales, en atención a su naturaleza, manifestamos que había tres clases: ordinario o comunes, especiales y arbitrales". En mismo sentido OrellanA (2005), p. 246, que señala "Los jueces árbitros también están contemplados en el artículo $5^{\circ}$ del COT, de los cual concluimos que los árbitros son tribunales distintos a los tribunales ordinarios y a los tribunales especiales".

59 En este sentido, Figueroa y Morgado (2013), p. 119 indican, respecto del artículo 222 del Código Orgánico de Tribunales, que "De este concepto legal es necesario destacar que el árbitro es un juez. El árbitro no es un equivalente jurisdiccional, y que sea un juez significa que asume las responsabilidades y deberes de tal, y, por lo tanto, su quehacer está sometido a las consecuencias civiles y penales por un mal desempeño. Las potestades disciplinarias de la Corte Suprema y la Corte de Apelaciones respecto de los árbitros, cuando se desvían de su correcto proceder".

60 SiLva (2014), p. 94, señala que "La reglamentación, en el Código recién mencionado y en el de Procedimiento Civil, de la institución de los jueces árbitros concuerda con el carácter público de su 


\section{Estado $^{61}$, siéndole aplicables los preceptos constitucionales contenidos en el capítulo sobre bases de la Institucionalidad, es decir los categoriza como órganos que forman parte del aparato judicial estatal, mismas ideas sostenidas por Colombo Campbell ${ }^{62}$. Una visión parcialmente diversa es la sostenida por Romero Seguel ${ }^{63}$ y Díaz Villalobos, quienes consideran al árbitro como juez, un tercero que debe ser designado por las partes ${ }^{64}$. El mentado juez es de carácter}

función, que los convierte en tribunales de la nación, sometidos a la superintendencia correctiva, correccional y económica de la Corte Suprema (...).

Es, asimismo, por su carácter de juez que a los árbitros se les exige el juramento antes de cumplir su tarea (arts. 236 COT, 646 del CPC y 1348 del Código Civil).

Por otra parte, los jueces arbitrales constituyen 'tribunales especiales' (...)".

${ }^{61}$ SiLva (2014), p. 92, señala que "que no puede olvidarse en momento alguno que, si el título de la función del árbitro sólo se origina en la selección de las partes, cuando su nombramiento no deriva directamente de la magistratura competente, en uno y otro caso lo convierte en agente de la sociedad organizada y lo compromete a iluminar con su sabiduría la oscuridad de la controversia. En virtud de esa calidad se constituyen los árbitros en órganos del Estado, a quienes se aplican los preceptos de la Constitución contenidos en el capítulo sobre Bases de la Institucionalidad referido a los principios de obligatoriedad de la Carta, de supremacía constitucional, de imperio de la ley y de nulidad de derecho público, a los requisitos de validez de la actuación de los órganos del Estado y a las responsabilidades y sanciones que se producen por su incumplimiento".

${ }^{62}$ Cоцомво (2014), p. 104, señala "En efecto, el Título IX del COT incorpora a los tribunales arbitrales entre los del sistema jurisdiccional nacional. Ello está en plena armonía con lo previsto en el art. $5^{\circ}$ del mismo Código, que expresa que 'a los tribunales mencionados en este artículo corresponderá el conocimiento de todos los asuntos judiciales que se promuevan dentro del territorio de la República, cualquiera que sea su naturaleza o la calidad de las personas que en ellos intervengan, sin perjuicio de las excepciones que establezcan la Constitución y las leyes'" y agrega "los jueces árbitros se regirán por el Título IX de este Código".

Como tribunales que son, los árbitros cuentan con todas las prerrogativas que les proporciona el "poder" de la jurisdicción y tiene todas las obligaciones y cargas que impone su "deber". Esta conclusión se presenta como especialmente relevante, ya que nuestro país tiene resuelto por ley, desde muy antiguo, que los árbitros son tribunales de justicia.

Deseo, finalmente, reforzar esta afirmación con el tenor literal del texto del art. 222 del COT, que define a los árbitros como "los jueces".

${ }^{63}$ Romero (1999), p. 411, indica "En rigor, no obstante su origen preferentemente privado, los árbitros en nuestro medio son reputados jueces en sentido propio, gozando sus sentencias de mérito ejecutivo sin necesidad de homologación judicial, quedando incluso los árbitros sometidos a ciertos controles propios de todo juez ordinario o especial, como es el caso de la jurisdicción disciplinaria que sobre los árbitros ejercen respectivamente las Cortes de Apelaciones y la Corte Suprema (art. CPE, $96 \mathrm{~N}^{\circ} 4$ y 540 COT)...".

${ }^{64}$ Romero y Díaz (2016), p. 53, señalan que "En el campo interno los árbitros son definidos como jueces nombrados por las partes, o por la autoridad judicial en subsidio, para la resolución de un asunto litigioso (art. 222 COT).

En esa lacónica definición se recoge una rica tradición proveniente del derecho romano, canónico y castellano, donde el árbitro -en cuanto a juez- debía ser siempre un tercero designado por las partes". 
privado $^{65}$, accidental, con diferencias respecto del juez ordinario, tales como la carencia de facultad de imperio por parte de los árbitros, o bien que estos no son funcionarios públicos, entre otras ${ }^{66}$. En esta misma línea sumamos a Jequier Lehuedé, aunque este niega que ejerzan la jurisdicción ${ }^{67}$. Por otra parte, diversos tratadistas rechazan la naturaleza jurisdiccional del arbitraje, negando que estemos frente a un tribunal. Así, Bordalí Salamanca sostiene que los árbitros no son tribunales de justicia que ejercen jurisdicción ${ }^{68}$, sino un equivalente jurisdiccional ${ }^{69}$, considerando que el árbitro no es un órgano permanentemente establecido ${ }^{70}$, tampoco es nombrado por un órgano estatal y

${ }^{65}$ ROMERO y Díaz (2016), p. 5, señalan que "La función del árbitro es la de un juez privado que
resuelve conflictos con eficacia de cosa juzgada; su sentencia, además, tiene el valor de un título
ejecutivo, sin necesidad de tener que pasar por una gestión de reconocimiento u homologación
judicial, salvo excepciones vinculadas con la protección de los incapaces". ${ }_{66}$ Sobre este punto ver Romero y Díaz (2016), pp. 4-6.

${ }^{67}$ Jequier (2013), p. 175, señala que "Jueces Estatales y árbitros participan entonces de la labor de administración de justicia porque así lo autoriza el ordenamiento constitucional, sin que por ello pueda confundirse sin embargo el concreto sitial institucional que a cada uno le corresponde. Los primeros como parte del Poder Judicial, constituyen órganos públicos que ejercen la función jurisdiccional de manera permanente, con estricta sujeción a la Constitución y la Ley y con potestad para interpretarla y aplicarla. Los árbitros, en cambio, son reflejo y consecuencia de la libre iniciativa y voluntad de las partes, reconocida también por la Constitución como valor humano fundamental, cuya autoridad -no potestad- emana de esa misma voluntad autónoma y se orienta, por lo mismo, a resolver los conflictos jurídicos dentro del preciso marco material que las partes también le han señalado". El mismo autor complementa en p. 460, nota 12, señalando "... En Chile, sin embargo, a diferencia de la experiencia española, la doctrina mayoritaria ha sostenido que a la luz de las normas constitucionales y legales precitadas, los árbitros tienen el carácter de jueces de la Nación, y, por ende, de tribunales especiales que forman parte del Poder Judicial y que ejercen la actividad jurisdiccional del Estado, sometidos por lo mismo a la superintendencia directiva, correccional y económica de la Corte Suprema. No compartimos sin embargo esta opinión, pues los árbitros, si bien son considerados como jueces por el Código citado y ejercen jurisdicción en el plano declarativo, no forman parte del Poder Judicial ni se identifican en modo alguno con los órganos permanentes que lo componen. Los árbitros hacen lo que el Poder Judicial, pero no son el Poder Judicial".

68 Bordalí (2016), p. 282.

${ }^{69}$ Bordalí (2016), p. 283, señala "No obstante la claridad de los textos legales y las autorizadas posiciones doctrinales antes referidas, sostengo, por el contrario, que el arbitraje no es una manifestación más de la función jurisdiccional, sino un equivalente jurisdiccional".

70 Bordalí (2016), p. 283, sostiene que "Se ha visto antes que uno de los requisitos que la Constitución chilena impone al ente aplicador del derecho, para que sea considerado verdadero órgano jurisdiccional, es que sea permanente y no transitorio, ad hoc, o comisión especial, según expresa el artículo $19 \mathrm{~N}^{\circ} 3$ inc. $5^{\circ} \mathrm{CPR}$. La Constitución chilena exige al órgano jurisdiccional que va a conocer y fallar una determinada causa civil o criminal, que esté establecido por la ley con anterioridad al acaecimiento de los hechos que dan origen a esa causa civil o criminal...". 
carece de facultad de imperio ${ }^{71}$. En esta línea podemos mencionar a Núñez ${ }^{72}$, Pérez Ragone y Vásquez ${ }^{73}$, criticando ${ }^{74}$ esta última el carácter de tribunal, entendiendo que el arbitraje no forma parte de la jurisdicción estatal ${ }^{75}$, sino que es un medio de resolución de disputas extrajudiciales ${ }^{76}$.

Ahora bien, de los aspectos examinados, podemos desprender elementos interpretativos que nos permitan forjar una opinión del punto señalado. En este sentido, del análisis de las fuentes en estudio, podemos concebir a los árbitros como una categoría de tribunal diversa de los jueces ordinarios estatales, que de igual modo ejerce la función jurisdiccional. Al respecto, si bien nuestra legislación no emplea conceptos generales ni clasificaciones sobre la materia, como lo hace la legislación castellana, entendemos que sigue un mismo camino en el tratamiento del arbitraje, concibiendo a los árbitros como una categoría diversa de tribunal. La influencia de las fuentes indicadas no sólo se desprende de la denominación "jueces árbitros" que utiliza el artículo 222 del Código Orgánico de Tribunales, a la usanza de las fuentes examinadas, sino que además lo apreciamos, en primer término, en la equiparación funcional entre los jueces árbitros y los jueces ordinarios por la que opta el legislador, pudiendo los árbitros resolver un conflicto de relevancia jurídica, mediante la dictación de una sentencia definitiva, dentro de un proceso preestablecido, al igual que un juez estatal. No obstante, esta equiparación legislativa en ningún caso se extiende al aspecto orgánico de los tribunales ordinarios, existiendo profundas diferencias entre estas categorías

\footnotetext{
71 Bordalí (2016), p. 284.

72 NúÑez y Pérez (2013), p. 330, ubican el estudio del arbitraje dentro de los sistemas alternativos de solución de conflictos, lo anterior para dar un estudio sucinto de su orgánica y a su funcionamiento básico.

${ }^{73}$ VÁsquez (2010), p. 192, señala "Así también, la fuerza que se concede a la decisión de un perito no es idéntica a la que emerge de un tribunal arbitral, pues ésta última es un equivalente jurisdiccional que puede exigirse por las vías contempladas a estos efectos, a diferencia de la anterior". A su vez VÁsquez (2014), pp. 244-245 indica: "Por otra parte, la relación existente entre el arbitraje y el Estado no puede comprenderse desde un estadio jurisdiccionalista, ya que, como señalamos, los árbitros no ejercen jurisdicción estatal, esta comprende un poder que no sólo reside en decir, sino también en ejecutar lo juzgado y esta última facultad no la tienen los árbitros. La función jurisdiccional se ejerce exclusivamente por los órganos del Estado en cuanto comprende un poder de este último y los árbitros no forman parte de dicho poder".

${ }^{74}$ En este sentido ver Vásquez (2018), pp. 15-52 y 115-150.

75 En esta línea de pensamiento podemos sumar a Chillón y Merino (1991), p. 27; Marín (2002), p. 226-227; Caivano (s/f), pp. 2-3; Cervantes (2009), pp. 60, 63 y 64; Yaurí (2013), pp. 3-5; San Cristóbal (2013), pp. 48-50; Maldonado y Montaña (2017), pp. 123-126; Riveros (2017), p. 120; OrRego (2004), pp. 440-443.

${ }^{76}$ VÁsQuez (2018), p. 148.
} 
de jueces, lo que descarta que los tribunales arbitrales formen parte del poder judicial o que estos sean empleados públicos, pues, tanto la legislación nacional sobre la materia, del mismo modo que las fuentes en estudio, no dan noticias respecto de tales afirmaciones.

La diversidad de categoría de jueces, así como la influencia de las fuentes en estudio, se aprecia además, en lo expresado en el actual artículo $5^{\circ}$ del Código Orgánico de Tribunales, texto que pese a tener algunas diferencias de redacción respecto del artículo $5^{\circ}$ original del Código Orgánico de Tribunales ${ }^{77}$, y el artículo $5^{\circ}$ de la ley de organización y atribuciones de los tribunales, mantiene su mismo espíritu, al regular conceptualmente en su inciso primero a los tribunales ordinarios indicando "Art. $5^{\circ} \mathrm{A}$ los tribunales mencionados en este artículo corresponderá el conocimiento de todos los asuntos judiciales que se promuevan dentro del territorio de la República, cualquiera que sea su naturaleza o la calidad de las personas que en ellos intervengan, sin perjuicio de las excepciones que establezcan la Constitución y las leyes". La disposición señalada, que tiene similitudes con la definición de juez ordinario plasmada en las Partidas, e idéntica noción a la utilizada por De Hevia en la conceptualización de jurisdicción ordinaria ${ }^{78}, y$, en definitiva, de los jueces ordinarios, no es compatible ni aplicable a los árbitros, pues estos no pueden conocer la universalidad de los asuntos que se promuevan, sea porque existen materias vedadas para los árbitros por razones de orden público, o bien, porque su intervención está limitada únicamente a conocer los asuntos específicos respecto de los cuales las partes le concedieron competencia.

Esta diversidad de categorías de tribunales era reconocida por Vargas Fontecilla, quien, en un artículo diverso al que trataba a los jueces ordinarios, el $6^{\circ}$ del proyecto original de la ley de organización y atribuciones de tribunales, regulaba a los jueces árbitros, separándolos de los tribunales ordinarios de justicia, manteniendo el espíritu de la legislación castellana y textos forenses usualmente empleados por los juristas de la época. La citada disposición fue suprimida por la comisión revisora, por defectos de redacción del texto, y no por razones de fondo. Así, tanto la ley de organización y atribuciones de

77 CASARINO (1943), pp. 7-8, indica en el artículo $5^{\circ}$ "A los tribunales que establece el presente Código estará sujeto el conocimiento de todos los asuntos judiciales que se promuevan en el orden temporal dentro del territorio de la República, cualquiera sea su naturaleza o la calidad de las personas que en ellos intervengan, con las solas excepciones siguientes...".

78 Para De Hevia (1790), p. 19, la jurisdicción Ordinaria implicaba conocer la universalidad de las causas, aunque sean de un mismo género, entendiendo que era perpetua y establecida por la ley, tratando a los jueces que se enmarcan en esta categoría como ordinarios. 
tribunales, como el Código Orgánico de Tribunales, tanto en la redacción original como la actualmente vigente, tratan conceptualmente a los tribunales ordinarios estatales en el artículo $5^{\circ}$, no mencionando a los jueces árbitros en dicha disposición, categoría especialísima de tribunal regulada sólo en un título especial. Lo anterior se mantuvo de manera inalterable hasta el año 1990 en que se modifica el Código Orgánico de Tribunales, agregándose el inciso final del articulo $5^{\circ}$ en que menciona a los jueces árbitros, modificación legal que en nada cambia lo razonado precedentemente, pues el inciso primero del artículo $5^{\circ}$ del citado cuerpo legal, sigue siendo inaplicable a los árbitros.

En razón de lo expresado, entendemos que el árbitro, en cuanto categoría de tribunal diverso, tiene un estatuto legal propio, distinto al de los jueces ordinarios estatales. En este sentido, no compartimos lo expresado por algunos tratadistas ${ }^{79}$ que sostienen, que, en cuanto a tribunal, a los árbitros se les exige y aplica idénticas obligaciones y deberes de los jueces ordinarios estatales. Respecto de lo señalado, tal como hemos sostenido, tanto la tradición castellana examinada como nuestra legislación, influenciada por las fuentes analizadas, equipara a los tribunales arbitrales con los jueces ordinarios estatales sólo desde una perspectiva funcional, mas no desde una vertiente orgánica, careciendo de fuentes que refuten lo expresado ${ }^{80}$. De lo anterior, podemos colegir que no es posible extrapolar las obligaciones y deberes de los jueces estatales a los jueces árbitros, no sólo considerando que son categorías de tribunales distintos, con profundas diferencias, sino que, además, no existe norma legal que lo establezca, ni fuentes que nos dé luces respecto de aquella afirmación. En este sentido, entendemos que el árbitro se debe regir por las normas constitucionales y legales aplicables a un órgano que ejerce la función jurisdiccional, con las restricciones que

\footnotetext{
${ }^{79}$ En este sentido Figueroa y Morgado (2013), p. 119; Colombo (2014), p. 104; Silva (2014), p. 92. Por su parte AYLwIN (2014), p. 181, en esta línea señala "Siendo los árbitros verdaderos jueces, deben aplicárseles las normas generales prescritas para éstos por la ley, cuando lo permita la naturaleza especial de sus cargos.

La calidad de juez, en efecto, otorga a su titular no sólo la competencia necesaria para decidir las cuestiones judiciales sometidas a su conocimiento, sino, además, cierto poder jerárquico sobre las partes que ante él contienden. En sentido inverso, le impone también algunos deberes, prohibiciones y responsabilidades inherentes a la función que ejerce".

${ }^{80}$ En este punto, debemos recordar que existen profundas diferencias entre estas categorías de tribunales, dentro de las que podemos mencionar el origen del árbitro, que depende de la voluntad de las partes, quienes fijan el marco de competencia en el que se desenvuelve, pudiendo incluso revocar la jurisdicción del árbitro. Por otra parte, los jueces estatales están sujetos en términos absolutos al principio de inexcusabilidad, lo que no ocurre en el arbitraje interno, pues existen causales por las cuales cesa la obligación del árbitro de resolver el conflicto, de conformidad al artículo 240 del Código Orgánico de Tribunales, misma solución empleada por el legislador castellano.
} 
impone las especiales características de esta categoría de tribunal, así como su estatuto legal propio.

\section{Requisitos normativos del proceso arbitral interno. Reflexiones sobre la asimetría de tales requisitos}

Los requisitos normativos del proceso arbitral interno, se desprenden de lo señalado en los artículos 236 y 240 del Código Orgánico de Tribunales, que aluden a la aceptación y el juramento por parte del árbitro. Mas, de aquellas disposiciones legales, no es posible colegir, a ciencia cierta, en qué momento surge el proceso arbitral, dejando una serie de interrogantes, tales como ¿si dichos requisitos son de existencia o validez del proceso arbitral o tienen otra entidad? o bien ¿cuál es la sanción ante la infracción de tales requisitos? En este ámbito, dada la aridez de las citadas disposiciones, no es posible colegir si la reclamación de la infracción de las normas legales señaladas se debe verificar dentro del juicio arbitral, saneándose tales vicios con la dictación de la sentencia definitiva, o, en cambio, se puede recurrir ante dichas infracciones, por medio de una acción de protección, ante la vulneración de la garantía constitucional que contempla la prohibición de ser juzgado por comisiones especiales.

En este aspecto, como se indicó, existen fallos emanados desde nuestros tribunales superiores de justicia, del siglo XIX, que, sin estudiar los requisitos del proceso arbitral de forma integral, se concentraban en determinar qué sanción procedía ante la falta de juramento por parte del árbitro. Así, los tribunales de la época entendían que la falta de juramento constituía un vicio que anulaba la sentencia dictada por el árbitro, debiendo las partes reclamar del señalado vicio necesariamente dentro del juicio arbitral, pues, una vez que el árbitro dictaba sentencia definitiva, el vicio señalado se saneaba; considerando algunos fallos al juramento como una garantía a favor de las partes, reclamable dentro del mismo juicio, antes de la dictación de la sentencia ${ }^{81}$.

Por su parte, la jurisprudencia nacional, con el pasar de los años, deja de concebir al juramento como una garantía a favor de las partes, entendiendo que el árbitro que no jurara actuaría con manifiesta incompetencia, pues este no cumplió con la forma legal de instalación de todo tribunal, razón por la cual este no puede ejercer válidamente sus funciones, aplicando los tribunales superiores de justicia la misma sanción que la jurisprudencia primitiva,

${ }^{81}$ En este sentido, ver notas 1 y 2. 
nulidad procesal, reclamable dentro del juicio arbitral ${ }^{82}$. Este último aspecto cambia en sentencia dictada por la Corte de Apelaciones de Concepción, la que concluye que cualquier actuación que el árbitro realice sin cumplir con la aceptación y juramento es ilegal, vulnerándose la garantía constitucional relacionada con la prohibición de comisiones especiales ${ }^{83}$.

Desde la dogmática nacional, Aylwin examina la aceptación y el juramento. Respecto de la aceptación, entiende que, mientras la aceptación no se preste, el nombramiento para el árbitro es un acto de terceros y, en consecuencia, inoponible ${ }^{84}$; una vez prestada el árbitro se obliga a desempeñar el cargo de compromisario ${ }^{85}$. Respecto del juramento, lo trata al examinar la instalación del tribunal arbitral, sosteniendo que los árbitros, como magistrados judiciales, necesitan también, una vez nombrados, instalarse legalmente para desempeñar sus funciones, remitiéndose a las normas contenidas en el párrafo $4^{\circ}$ título $X$, aplicable a los jueces ordinarios ${ }^{86}$. Finalmente estima que la falta de juramento no puede afectar la validez de la convención arbitral, tampoco del contrato de compromisario, sino que afecta las actuaciones mismas del tribunal, estaríamos frente a un vicio procesal reclamable recursivamente dentro del proceso arbitral ${ }^{87}$, afirmando lo señalado por la jurisprudencia de los tribunales superiores de justicia durante el siglo XX. Casarino sigue idénticas ideas ${ }^{88}$, reflexionando sobre la evolución de la sanción de ambos requisitos, desde la nulidad absoluta ejerciendo la acción ordinaria de nulidad, hasta la nulidad procesal ${ }^{89}$. Figueroa Yávar y Morgado San Martín entienden que tanto la aceptación y el juramento se deben realizar conjuntamente, siendo ambos requisitos de la esencia del arbitraje, de manera que su ausencia importa falta de jurisdicción, y en consecuencia, incapacidad absoluta para desempeñarse como tal. Respecto del juramento, sigue la

\footnotetext{
${ }^{82}$ Ver notas 3, 4, 5 y 6.

${ }^{83}$ Ver nota 7 al respecto.

${ }^{84}$ AYLWIN (2014), p. 359.

85 AYLWIN (2014), p. 368.

86 Para Aytwin (2014), pp. 378-379: "El juramento instalatorio ha sido establecido como una garantía de buena administración de justicia y debe ser considerado, en consecuencia, como una formalidad de carácter público. En el caso de los árbitros, no obstante, esta garantía dice relación únicamente con las partes a quienes alcanza la jurisdicción arbitral, por lo cual los tribunales no la estiman en estos casos como requisito de orden público".

87 AyLWIN (2014), pp. 380-381.

${ }^{88}$ CASARINO (2006), p. 20.

${ }^{89}$ CASARINo (2006), p. 21.
} 
misma corriente de pensamiento ya señalada ${ }^{90}$. Finalmente, Romero Seguel y Díaz Villalobos tratan el tema a propósito de la instalación del tribunal ${ }^{91}$, indicando, respecto del arbitraje interno, que la instalación requiere siempre del cumplimiento formal de la aceptación del cargo por parte del árbitro y del juramento de rigor. Respecto de la aceptación la conciben como un acto unilateral y voluntario; por su parte, entienden que el juramento ${ }^{92}$ se debe prestar rigurosamente, pues la falta de este en el arbitraje interno hace que el árbitro carezca de competencia y se convierta en comisión especial, la que está prohibida expresamente por la CPR para juzgar un conflicto judicial ${ }^{93}$.

Desde la otra corriente, Vásquez Palma sostiene que el nombramiento del árbitro no lo obliga a desempeñar el cargo, pues es un acto de terceros que le es inoponible y no basta para hacer surgir el juicio arbitral, sólo la aceptación de aquél puede incoar dicho procedimiento y generar una relación de derecho entre las partes, colocando al árbitro en la necesidad de desempeñar el $\operatorname{cargo}^{94}$. Por su parte, concibe al juramento como un medio legal de instalación de los jueces árbitros, indicando que ante la falta de este el árbitro actuaría con manifiesta incompetencia, siguiendo lo señalado mayoritariamente por la jurisprudencia nacional. En este aspecto, critica este requisito, pues entiende que este se concibe como una obligación que surge como consecuencia del intento de asimilar a los árbitros con un juez estatal, reafirmando la concepción judicial del árbitro en Chile. Es por lo señalado que sostiene que el requisito mencionado debe suprimirse, pues los árbitros no forman parte del aparato jurisdiccional estatal, siendo un requisito intrascendente para el instituto arbitral ${ }^{95}$.

Ahora bien, en el análisis de los requisitos normativos del proceso arbitral voluntario interno, debemos tener presente lo concluido previamente, es decir, que estamos frente a una categoría de tribunal especialísimo, con reglas propias y diversas de aquellas aplicables los jueces ordinarios, que ejercen

\footnotetext{
90 Figueroa y Morgado (2013), pp. 133-134.

91 Mismo tratamiento que le da Cоцомво (2014), p. 107, señalando que "El juez debe aceptar el cargo, declararlo expresamente así y jurar que lo desempeñará con la debida fidelidad y en el menor tiempo posible. En ese mismo instante pasa a constituirse en juez, posición que lo habilita para ejercer jurisdicción en el tribunal arbitral".

92 Romero y Díaz (2016), p. 134. Cabe señalar que los tratadistas en la nota 228 señalan que "la existencia del juramento en el arbitraje es otra reminiscencia de la equivalencia entre la judicatura ordinaria y la función de los árbitros que hemos heredado del derecho castellano...".

93 Romero y Díaz (2016), pp. 134-135.

94 VÁsquez (2018), p. 226.

95 VÁsQuez (2018), pp. 228-230.
} 
la función jurisdiccional, y su fuente inmediata es la voluntad de las partes ${ }^{96}$ por medio del compromiso; aspecto que consideraremos al interpretar las normas pertinentes. Así las cosas, entendiendo que la fuente inmediata de la función jurisdiccional del juez árbitro es la voluntad de las partes en el compromiso, lo que permite la Constitución y la ley, es necesario preguntarse ¿si basta el nombramiento del árbitro en el compromiso para el nacimiento del proceso arbitral?

La respuesta es negativa, pues los artículos 236 y 240 del Código Orgánico de Tribunales exigen, en primer término, la aceptación del árbitro, exigencia que no sólo se requiere para el perfeccionamiento del contrato de compromisario ${ }^{97}$, sino que, además, es requisito indispensable para que el árbitro esté obligado a resolver el conflicto de relevancia jurídica, y consecuencialmente, surja el proceso arbitral ${ }^{98}$. La exigencia antes señalada no es original de nuestra ley, pues, como se ha señalado, tanto en la legislación castellana, así como en los textos forenses examinados, se establecía tal requisito; siendo los modelos legales que nuestro legislador consultó al recepcionar al arbitraje en nuestra legislación. En este contexto, la aceptación no sólo tiene relevancia en el vínculo civil que une a las partes con el árbitro, pues, una vez que manifiesta de cualquier modo su voluntad de resolver la controversia jurídica, surge, como se indicó, la obligación de resolver el conflicto dentro de un proceso establecido previamente, naciendo el vínculo procesal que une a todos los actores en el juicio arbitral. A partir de ese momento, el árbitro puede y está obligado a ejercer la función jurisdiccional, como tribunal especialísimo, distinto de un juez ordinario, pues, a diferencia de este último, el árbitro sólo está obligado a resolver el conflicto a partir de la

\footnotetext{
${ }^{96}$ Jequier (2011), p. 461, sostiene que "Desde sus orígenes más remotos, el arbitraje encuentra su fundamento y razón de ser en la libertad de las partes, quienes ejerciéndola optan precisamente por renunciar a la jurisdicción del juez ordinario predeterminado por la ley, para confiar la solución de sus conflictos al árbitro".

97 En este aspecto, AyLwin (2014), p. 360. Señala "el convenio que ata a las partes con el árbitro tiene individualidad propia y diversa a la que celebran los litigantes entre sí para acordar el arbitraje. Dicho acto, no genera la jurisdicción arbitral, que está creada por la ley y a la cual las partes están de antemano sujetas por mandato legislativo o se han acogido voluntariamente por acuerdo entre ellas. Su único efecto es crear para la persona designada la obligación de ejercer la tarea de árbitro y, por lo común, para las partes litigantes la obligación de remunerarle sus servicios con un honorario". Por su parte VÁsquez (2018), p. 227 señala "La importancia de la aceptación podría resumirse en el hecho que con ella surge una relación obligacional recíproca entre las partes del convenio y el o los árbitros nombrados. Con la aceptación, el árbitro se obliga a cumplir su encargo, dentro de plazo y formas estipuladas o la ley en subsidio, y para las partes, nace el deber de remunerar esas funciones".
}

${ }^{98}$ En este sentido VÁsquez (2018), p. 226. 
aceptación y no antes, cesando dicha obligación por las causales indicadas en el mismo artículo, razones no aplicables a los jueces estatales, y que sin duda restringen la aplicación del principio de inexcusabilidad a los jueces árbitros ${ }^{99}$.

En este sentido, si nosotros interpretáramos de forma aislada los artículos 235 y 240 del Código Orgánico de Tribunales, pudiéramos concluir que tales disposiciones son aplicables al compromiso y el contrato de compromisario, sin estar vinculadas al ejercicio de la función jurisdiccional antes señalada, dado que dichas normas utilizan expresiones tales como "aceptado el encargo" o "evacuar el encargo", que denotarían un mandato o prestación civil de servicios. Sin perjuicio de ello, es necesaria la interpretación armónica de dichas normas en relación con el artículo 222 de dicho cuerpo normativo, el cual, al conceptualizar a los jueces árbitros, nos indica su función, la resolución del asunto litigioso, manifestación propia del ejercicio de la función jurisdiccional ${ }^{100}$, aspecto ya reconocido en las fuentes examinadas, incluso de forma expresa en el artículo 213 del proyecto de Vargas Fontecilla, texto modificado por la comisión revisora sólo por problemas menores de redacción, sin que medien razones de fondo, de acuerdo a lo ya expresado.

Respecto de la forma en la que se debe verificar la aceptación, el artículo 236 del Código Orgánico de Tribunales indica que "... el árbitro que acepta el encargo deberá declararlo así...". Dicha disposición debe interpretarse en su real sentido, que va más allá del mero cumplimiento de una formalidad, la cual se debiera expresar por escrito. Por el contrario, la aceptación del encargo se puede desprender de cualquier acto del supuesto proceso arbitral, del que se manifieste inequívocamente la voluntad del particular de asumir el encargo, perfeccionándose el contrato de compromisario, por una parte, y consolidándose la función jurisdiccional, por otra. De las fuentes examinadas, particularmente las Partidas, nada señalaban respecto de exigencias formales vinculadas con la aceptación del árbitro, misma línea que sigue los textos forenses estudiados y el proyecto de Vargas Fontecilla. Sólo en

\footnotetext{
${ }^{99}$ Colombo (2014), p. 108, concibe la aplicación del principio de inexcusabilidad en términos absolutos al árbitro señalando que "esta regla constitucional se les aplica plenamente, pero sólo a contar del momento en que el árbitro acepta desempeñar el cargo. Ello es una consecuencia del sistema de designación que tienen los jueces árbitros". No estamos de acuerdo con tal conclusión, pues el tratadista no considera el artículo 240 del Código Orgánico de Tribunales, que establece varias causales por las cuales el árbitro cesa en la obligación de resolver el asunto, razones no aplicables a los jueces ordinarios ni especiales.

100 Como señala Colombo (1997), p. 336, "el acto jurídico privativo e inherente al ejercicio de la función jurisdiccional del tribunal es la resolución judicial. Ella es la forma normal y habitual que el tribunal tiene de manifestar su voluntad en el proceso".
} 
el texto aprobado por la comisión revisora aparece la frase "el árbitro que acepta el encargo deberá declararlo así", texto que se toma del artículo 1328 del Código Civil, que le sirvió de modelo, sin que existiera mayor debate en la comisión revisora ${ }^{101}$.

En cuanto a los orígenes del mencionado artículo 1328 del Código Civil, podemos señalar que en el inicio del proceso de recepción del derecho civil, y fundamentalmente a partir de la promulgación de la ley de 10 de septiembre de 1840, la cual crea la comisión de legislación del Congreso que se encargaba de la "Codificación de las Leyes Civiles"102-103, el legislador opta por un proceso de codificación, desechando otras alternativas de fijación del derecho civil $^{104}$, dando un fuerte impulso a tan magna empresa. Desde el año señalado comienzan los trabajos de la Comisión de Legislación, encargada de la redacción del Código y, posteriormente, la Junta Revisora, ocupada de revisar los trabajos despachados por la primera, surgiendo al efecto dos proyectos, uno que trataba el título preliminar y la sucesión por causa de muerte, y el segundo de los contratos y obligaciones convencionales, todos publicados en El Araucano desde el año 1841 a 1847. El segundo proyecto que contenía los dos libros señalados fueron publicados íntegros, pero por separado, el año 1846 y 1847 , respectivamente ${ }^{105}$. Respecto de los proyectos antes señalados, estos no contemplaban norma legal referente a la aceptación y el juramento del partidor ${ }^{106}$.

Dado que la Comisión Legislativa señalada funcionó hasta el año 1845, desde el año 1847 Andrés Bello se dedicó, individualmente, al desarrollo y

101 Ballesteros (1890), p. 121. Con la sola excepción de la crítica del señor Lira, miembro de la comisión, quien consideraba al texto original de Vargas Fontecilla como una mera norma de procedimiento, no adecuada a la ley de organización y atribuciones de los tribunales.

102 GuZmán (1979), p. 321.

103 Para Guzmán (1979), p. 321, "La Comisión dejó de funcionar en 1845, y el Código Civil promulgado en 1855 fue en definitiva la obra de Bello. Pero el establecimiento de dicho cuerpo dio el impulso decisivo a la codificación y creó el marco oficial adecuado en el que Bello pudo insertar sus ideas y sus proyectos".

104 Para GuZmán (1979), p. 316, “Históricamente la fijación se ha desarrollado con una gran variedad de formas y contenidos, y especificado, por ende, en diversos modos concretos de fijación. Uno de estos modos es la codificación, nacido en Europa central a mediados del s. XVII y todavía perdurante. De esta manera, codificación no significa el hacer códigos, sino el hacerlos de una determinada manera; precisamente, de aquella manera que se ideó a partir de la época indicada. Ello implica que también puede hacerse códigos de una manera diferente, como es el caso, por ejemplo, de las recopilaciones".

105 GuZMán (1979), p. 326.

106 Bello (1887), pp. 130-137 y pp. 387-394. 
mejora de los proyectos antes señalados, fruto de lo cual surge el proyecto de Código Civil de 1853 107-108. Dicho Proyecto agrega la aceptación y el juramento, pero con exigencias adicionales a las que conocemos. Así el artículo 1506 señalaba que "El partidor que acepta el encargo, deberá declararlo así ante el juez con exhibición del testamento, decreto judicial, o título auténtico del comitente o comitentes; $i$ jurará desempeñarlo con la debida fidelidad, $i$ en el menor tiempo posible ${ }^{\prime \prime 109}$. Claramente, el texto del proyecto de 1853 fija formalidades a la acepción, exigiendo que se verifica ante el juez ordinario, debiendo exhibir el partidor documento donde conste su nombramiento. Dichas formalidades son suprimidas en el proyecto inédito ${ }^{110}$, quedando el texto en los términos que rige actualmente ${ }^{111}$, de lo que colegimos que tal declaración se puede realizar sin ninguna formalidad ${ }^{112}$ e incluso tácitamente ${ }^{113}$. De lo señalado, necesariamente entendemos que la aceptación es un requisito de existencia del proceso arbitral, sin el cual el árbitro no está obligado a resolver conflicto alguno dentro del proceso preestablecido, ni menos aún corre un plazo fatal para la dictación de la sentencia definitiva,

\footnotetext{
107 Para GuZmán (1979), p. 327, “b) Desde 1847 a 1853. Este período corresponde al trabajo solitario de Bello, destinado a corregir y desarrollar el Título Preliminar y los libros sobre sucesiones (libro III) y obligaciones y contratos (libro IV), y a redactar el libro De las personas (libro 1) y De los Bienes, y de su dominio, posesión, uso y goce 80 (libro II). Fruto de este trabajo es el Proyecto de 1853, Ilamado así por haberse editado por partes en ese año, si bien quedó terminado a mediados de 1852".

108 Sobre el tema ver Guzmán (1982), pp. 341-343.

109 Bello (1888), p. 356.

110 Bello (1890), p. 339.

111 BeLlo (1981), p. 305.

112 VÁsquez (2018), p. 226, señala "Nosotros, en cambio creemos que se trata de un contrato consensual que no requiere en verdad ninguna formalidad, pues el art. 236 sólo lo obliga a declarar su aceptación, mas no plantea una formalidad adicional para que aquélla se configure o valide".

113 Orrego (1985), p. 95, da cuenta que la Corte Suprema, en sentencia de 12 de mayo de 1969, acoge la posibilidad de aceptación tácita del árbitro señalando "Aceptado de hecho el compromiso por el árbitro al desempeñarlo, ello es suficiente para perfeccionar el vínculo contractual entre el árbitro y las partes, sujetándolo a las obligaciones del contrato de compromiso en orden al desempeño del encargo.

No hay ley que exija una aceptación solemne y expresa". En este sentido AyLwIN (2014), p. 365 señala "No compartimos esta opinión y nos parece que sería absurdo que se pudiera dejar sin efecto la sentencia pronunciada por un árbitro a pretexto de que éste no había aceptado el cargo. Lo que la ley quiere es que no se pueda obligar a nadie a desempeñar las funciones de árbitro, sino cuando haya declarado expresamente que acepta ejercerlas. La aceptación del árbitro no puede, al efecto, deducirse de su simple silencio o de cualquier actitud aparente de su parte. Pero si en el hecho comienza a desempeñar el cargo de compromisario y dicta resoluciones en calidad de tal, estos actos constituyen una declaración inequívoca de su aceptación".
} 
siendo irrelevante el requerimiento de las partes, a diferencia de lo que ocurre con los jueces estatales, a quienes les rige en plenitud la inexcusabilidad.

El segundo requisito normativo del arbitraje es el juramento, formalidad que, a diferencia de la aceptación, no tiene su fuente en el derecho castella$n^{114}$, pues dicha legislación sólo exigía la aceptación por parte del árbitro. Lo señalado es seguido por los citados textos forenses, con excepción de Eugenio de Tapia, quien entiende que los jueces árbitros deben jurar antes de aceptar el encargo o a lo menos antes de dictar la sentencia, de que ni por odio, enemistad, amor, temor, dádivas, promesas ni otra causa, dejarán de cumplir fielmente su oficio según su inteligencia; dando cuenta que así se practica ${ }^{115}$. Vargas Fontecilla, al redactar el artículo 224 del proyecto, mantiene la esencia de lo señalado por De Tapia en Febrero Novísimo, pero reemplaza la fórmula negativa del juramento ya señalada, prefiriendo una fórmula positiva, al igual que el artículo 1328 del Código Civil, empleando la expresión "jurar desempeñar su cargo con toda fidelidad" suprimiendo las restantes expresiones utilizadas por De Tapia, las que no tenían cabida dada la fórmula del juramento empleada. Sin perjuicio del cambio en la forma de redactar la fórmula del juramento, el sentido en ambos casos es el mismo, concebir al juramento como una garantía del árbitro frente a las partes, asegurando que este ejercerá sus funciones adecuadamente, exento de cualquier factor externo que pudiera afectar su independencia e imparcialidad. El proyecto original exigía una oportunidad para cumplir con el juramento, al momento de aceptar, lo cual se suprime por la comisión revisora, la que opta por utilizar la redacción del artículo 1328 del Código Civil.

Del estudio formulado, no tenemos elementos que nos permitan concluir que el juramento es un requisito para la instalación del tribunal arbitral. En primer término, el sentido del juramento es prestar una garantía a las partes, en el sentido de que el árbitro ejercerá la función jurisdiccional con la

\footnotetext{
114 En este punto disentimos de lo señalado por Romero y Díaz (2016), p. 134, quienes en la nota 134 sostienen que "La existencia del juramento en el arbitraje es otra reminiscencia de la equivalencia entre la judicatura ordinaria y la función del árbitro que hemos heredado del derecho castellano". El derecho castellano, tal como hemos sostenido, nunca exigió a los árbitros jurar, ni las Partidas, ni la Novísima Recopilación dan noticias de tal requisito. La literatura jurídico procesal forense tampoco se refiere al juramento, salvo Eugenio de Tapia, en su texto Febrero Novísimo, el que da cuenta de una práctica de tribunales.

115 De Tapia (1828), p. 35. Este aspecto es ratificado por Ballesteros (1890), p. 122, el que señala "Aunque Hevia Bolaños sostiene en la Curia Filípica, apoyado en la opinión de Parladorio, Escobar i Covarrubias, que no era necesario que los árbitros i los arbitradores prestasen juramento de cumplir bien i fielmente con su encargo, manifiesta Tapia en el Febrero Novísimo haberse introducido en la práctica el que jurasen que ni por odio, enemistad, amor temor, dádivas, promesas ni otra causas dejarían de hacer fielmente su oficio, según su inteligencia".
} 
debida fidelidad, exento de todo elemento que afecte su independencia e imparcialidad; nunca se estableció como exigencia para que el árbitro pueda iniciar el ejercicio de sus funciones, lo que ratifica el artículo 240 del Código Orgánico de Tribunales, pues sólo a partir de la aceptación, no del juramento, el árbitro estará obligado a resolver el conflicto, pudiendo jurar en cualquier momento, incluso antes de fallar. Distinta es la situación de los jueces estatales, pues estos no sólo emplean una fórmula distinta de juramento, sino que además, sólo una vez que juren, y no antes, iniciarán el ejercicio de sus funciones de acuerdo al artículo 305 del citado cuerpo legal. Por lo demás, dado que estamos frente a una categoría de tribunal distinta a los jueces estatales, con estatuto legal propio, no es posible exigirles ni aplicarles idénticas obligaciones y deberes de los jueces estatales. Cabe hacer presente, que el juramento del árbitro es irrelevante para efectos de la consolidación de la función jurisdiccional e inicio del proceso arbitral, bastando la aceptación del encargo para que el árbitro pueda ejercer sus funciones en dicho juicio. Es por lo anterior que la falta de juramento, formalidad legal que concebimos como garantía de independencia e imparcialidad en favor de las partes, debe ser alegada por estas durante el juicio arbitral, antes que se dicte sentencia definitiva, pues una vez resuelto el conflicto, el vicio procesal señalado se sanea, no siendo posible su reclamación fuera del juicio arbitral.

En virtud de lo señalado, entendemos que las exigencias normativas de los artículos 236 y 240 del Código Orgánico de Tribunales son asimétricas. En este ámbito, debemos recordar que el juicio ante el juez árbitro, sea de derecho arbitrador o mixto, no es otra cosa que un proceso, con mayores o menores formalidades, sujeto a requisitos de existencia' ${ }^{116}$, cuya infracción acarrea la inexistencia del proceso; otro tipo de vicios serían infracciones a requisitos de validez de los actos procesales, los cuales adolecerían de nulidad procesal ${ }^{117}$. Sin duda que la falta de aceptación del árbitro impide que

\footnotetext{
116 Colombo (1997), pp. 147-167. El autor concibe al proceso como un acto procesal complejo, que requiere cumplir una serie de requisitos para su nacimiento o existencia, entre los cuales se encuentra el conflicto de intereses de relevancia jurídica, la jurisdicción y la acción cuando constituye presupuesto del proceso; sólo si se infringe alguno de los presupuestos señalados se configuraría la inexistencia del proceso. Otro tipo de vicios son infracciones a requisitos de validez de los actos procesales, los cuales adolecerían de nulidad procesal.
}

117 Otero (2010), pp. 42-49. El tratadista, al igual que Colombo, señala los requisitos de existencia del proceso, en términos generales, indicando que estos son: la existencia de un conflicto de relevancia jurídica, la existencia e individualidad de las partes y la existencia de un tribunal absolutamente competente. Respecto de este punto sostiene que "Lo primero es determinar si se está en presencia de un tribunal, o sea, ante quién tiene jurisdicción conforme a lo establecido por la ley. Sin jurisdicción no hay proceso. Esto es, el o los jueces que conforman el tribunal deberán haber sido debida y legalmente investidos como tales, cumpliendo cabalmente todos y cada uno de los 
ejerza la función jurisdiccional, no estando obligado a resolver el conflicto, por lo que sin que medie ésta el proceso arbitral es inexistente, razón por la cual todos los actos, supuestamente procesales, que ejecute el individuo sin que medie la aceptación, son manifestaciones ajenas al ejercicio de la función jurisdiccional, por lo tanto son inexistentes, siendo posible desconocer sus efectos por cualquier individuo, en cualquier momento y por cualquier herramienta legal idónea ${ }^{118}$, incluso una acción de protección ${ }^{119}$. El juramento, como indicamos, tiene un cariz diverso, pues este requisito normativo no provoca ni el perfeccionamiento del contrato de compromisario, ni es relevante en la consolidación de la jurisdicción en árbitro, quien puede ejercer la función a partir de la aceptación, siendo plenamente competente, pudiendo jurar en cualquier momento antes de dictar sentencia definitiva. En este sentido, el juramento no es un requisito de existencia del proceso arbitral, sino una garantía del árbitro en favor de las partes en el sentido de desempeñar fielmente su función exento de todo elemento que pudiera afectar la independencia e imparcialidad del árbitro, razón por la cual, frente a la infracción normativa señalada, dictando el árbitro la sentencia definitiva sin jurar, las partes pueden reclamar necesariamente dentro del proceso arbitral, pues una vez que la sentencia definitiva se encuentre firme, el vicio procesal señalado se sanea ${ }^{120}$. A su vez, disentimos de las voces que solicitan suprimir legislativamente el juramento en esta materia. En este ámbito, parte de las razones que sustentan dicha petición se apoyan en una falsa interpretación de la mentada exigencia normativa, desvirtuando el juramento, el que migra desde una concepción de garantía que el árbitro presta a las partes, a un medio legal de instalación del tribunal, sin el cual este carece de competencia

requisitos que la Constitución y la ley establecen para ello. Si falta alguno de estos requisitos, el juez, aunque haya sido nominado como tal, carecerá de jurisdicción, como ser si la Contraloría no ha tomado razón de su nombramiento o, habiéndolo hecho, el juez no ha prestado el juramento de rigor o no se cumplen los requisitos para desempeñar el cargo. Lo mismo ocurre en aquellos casos en que la ley ha otorgado jurisdicción a una autoridad administrativa".

118 Colombo (1997), p. 166.

${ }^{119}$ Como señala Sııva (2014), p. 100, "en orden al recurso de protección (art. 20 de la Carta), en principio ha de ser considerarse inadmisible en cuanto afectare a la actuación del árbitro que se mueva dentro del marco que le corresponde, tal como, en la misma hipótesis, es igualmente improcedente respecto de la magistratura ordinaria. Distinta es la situación si el árbitro o juez realizan actos y omisiones que, al margen de la jurisdicción, amenacen, perturben o atropellen el legítimo ejercicio de los derechos constitucionales garantizados con tal recurso".

120 Salas (2013), p. 75 señala "la nulidad procesal, como la civil, no producen efectos de pleno derecho. Debe ser declarada por el juez, y mientras ello no ocurra, al acto irregularmente ejecutado se le atribuirán todos los efectos señalados por la ley y queda saneado definitivamente una vez terminado el pleito". 
para conocer el asunto, pretendiendo equiparar orgánicamente ambas categorías de tribunales, pese a la inexistencia de fuentes legales que justifiquen lo indicado. Por lo demás, la visión de intrascendencia del juramento en el arbitraje, que sostiene Vásquez, se ancla en sustentos pragmáticos del instituto arbitral, plenamente aplicable a otras materias, como el peritaje, la prueba de testigos, la prueba confesional, entre otras; no obstante, entendemos que el juramento escapa de esta visión, siendo relevante socialmente que la persona que asuma dicha función otorgue una garantía a las partes del proceso, asegurando que ejercerá dicha tarea justamente, con la debida independencia e imparcialidad, estándar mínimo que una comunidad puede pedir a quien desempeña tan noble tarea.

Respecto de la jurisprudencia que, ante la infracción de los requisitos señalados, concibe a los árbitros como una comisión especial, no sólo desvirtúa la interpretación del tema en análisis, sino que se aparta de la propia Constitución. En este sentido, de acuerdo a Lübbert ${ }^{121}$, esta concibe la prohibición de comisiones especiales ${ }^{122}$ como barrera al establecimiento de órganos creados para juzgar a un determinado grupo de personas, con posterioridad a acaecidos los hechos, sin que se garantice la independencia e imparcialidad del sentenciador, pretendiendo evitar que se creen tribunales, para juzgar con dureza o liviandad a un grupo de individuos ${ }^{123}$. Luego, para identificar la existencia de una comisión especial ${ }^{124}$ basta que no se verifiquen los presupuestos señalados por el constituyente, es decir, que la fuente del tribunal no sea la ley y que el tribunal sea establecido o creado con posterioridad a la verificación de los hechos que sustentan la controversia

\footnotetext{
121 LüвBERT (2011), pp. 93-94, sostiene que la prohibición de comisiones especiales apunta a la prohibición de establecimiento de tribunales ad hoc, creados para juzgar un caso concreto o a una determinada persona o grupo de personas en particular, sin que se garantice la imparcialidad e independencia del juzgador, vulnerando el principio de igualdad conforme al cual todos los ciudadanos en idénticas situaciones deben ser juzgados por el mismo tribunal. Idéntico sentido tiene la exigencia de irretroactividad de ley que crea un tribunal. Se busca evitar que luego de ocurrido un hecho se cree un tribunal con el solo objeto de juzgar con mayor o menor rigor a determinada persona o determinados hechos.

122 Sobre el tema ver García y Contreras (2013), pp. 258-260.

123 García y Contreras (2011), pp. 259-260, da cuenta de fallos del tribunal constitucional sobre la materia, indicando "EI TC ha entendido que la comisión especial es la expresión que la Constitución emplea para designar 'a todo órgano que usurpa atribuciones jurisdiccionales y pretende asumirlas sin haber sido atribuido de ellas conforme a derecho'". En similar sentido, se ha precisado que "toda persona que pretense desempeñarse como juez de esos tribunales, sin haber sido instituida por el legislador, sino por un mero acto administrativo, se constituye en una comisión especial expresamente prohibida por la Constitución".
}

124 Sobre el tema SiLva (1996), pp. 189-190 y SiLVA (2002), pp. 43-50. 
jurídica. En materia de arbitraje voluntario, la Constitución y la ley establecen los tribunales arbitrales, permitiendo el legislador que las partes opten libremente por este mecanismo, regulando tanto los aspectos orgánicos como funcionales de dicha categoría, siendo de vital importancia la voluntad de las partes en su configuración. Respecto del segundo presupuesto, pensamos que es suficiente para el cumplimiento de la normativa constitucional que el tribunal esté establecido legalmente en términos abstractos, pudiendo las partes nombrar al árbitro en el compromiso antes que surja conflicto, o incluso después, como sería el caso de un juez árbitro nombrado en subsidio por la Justicia Ordinaria a falta de acuerdo entre las partes.

\section{Conclusiones}

El estudio de fuentes que el codificador procesal nacional tuvo a la vista al elaborar la ley de organización y atribuciones de los tribunales nos entregó elementos interesantes en el estudio del arbitraje interno en general, así como de los requisitos normativos del proceso arbitral en Chile, pudiendo comprender como se construyeron las normas legales sobre la materia. En este sentido, entendemos, a la luz de lo expuesto en el presente trabajo, que los árbitros son una categoría especialísima de tribunal, diversa a los jueces ordinarios estatales, optando el legislador nacional por una equiparación funcional entre tales categorías de jueces, mas no una equiparación orgánica. En virtud de aquello, entendemos que no es posible aplicar por extensión idénticos deberes y obligaciones de los jueces ordinarios a los jueces árbitros, los que, como categoría independiente y autónoma de tribunal, tienen un estatuto legal propio que les rige. En razón de lo señalado, no es posible interpretar los artículos 236 y 240 del Código Orgánico de Tribunales a la luz de las normas del título $\mathrm{X}$ párrafo $4^{\circ}$ del citado Código referente a la instalación de los tribunales, siendo indispensable determinar el verdadero sentido y alcance de los artículos señalados. Al efecto, los requisitos normativos del proceso arbitral son la aceptación y el juramento, que tienen una consideración y tratamiento legal diverso, por lo que entendemos que son asimétricos. En este sentido, la aceptación es un requisito de existencia del proceso arbitral, sin el cual el árbitro no está obligado a resolver conflicto alguno dentro del proceso preestablecido, ni menos aún, corre un plazo fatal para la dictación de la sentencia definitiva, siendo irrelevante el requerimiento de las partes, a diferencia de lo que ocurre con los jueces estatales, a quienes se les aplica en términos absolutos el principio de inexcusabilidad. Sólo a partir de la aceptación por parte del árbitro, el proceso surgirá, pudiendo este ejercer la función jurisdiccional. En virtud de lo señalado, ante la infracción de la aceptación, es posible desconocer los efectos del acto procesal, pudiendo solicitarse al 
tribunal que lo declare en dichos términos, siendo posible ejercer por la parte afectada cualquier medio idóneo para reclamar lo señalado, incluso una acción de protección. Por contrapartida, el juramento no es concebido por el legislador como un requisito de instalación del juez árbitro, ni como requisito para que el árbitro ejerza sus funciones. El legislador establece el juramento del árbitro como una garantía que este presta a las partes, de desempeñar correctamente su función, ajena a cualquier elemento que pueda afectar su independencia e imparcialidad, pudiendo prestarse, sea espontáneamente o a petición de las partes, en cualquier momento del proceso arbitral, incluso antes de dictarse sentencia definitiva. En virtud de lo indicado, concluimos que el juramento no es un requisito de existencia del proceso arbitral, siendo el juez competente con su mera aceptación; sino que es una garantía legal, la cual, ante su infracción, puede reclamarse por las partes antes que la sentencia se encuentre firme o ejecutoriada, pues posteriormente a dicho momento, el vicio procesal señalado se sanea.

\section{BiBLIOGRAFíA CITADA}

Abeliuk Manasevic, René (2014): "El arbitraje y las obligaciones de las partes y del árbitro", en: A.A. V.V., Estudios de Arbitraje en homenaje a Patricio Aylwin Azócar, $2^{a}$ edición (Santiago, LegalPublishing Chile), pp. 9-26.

Alcaraz y Castro, Isidoro (1828): El método y práctica de los cuatro juicios: Civil ordinario, sumario de partición, ejecutivo, y general de concurso de acreedores, $5^{a}$ edición (Madrid, con licencia por don Julian Viana Razola).

Alonso El IX (1844): Las siete partidas del Sabio rey d. Alonso el IX: con las variantes de mas interés y la glosa del lic. Gregorio López (Traducc. Ignacio Sanponts y Barba et al., Barcelona, Imprenta de Antonio Bergnes), Tomo II.

Alfonso XI (1847): El Ordenamiento de las Leyes que el rey Alfonso XI hizo en las Cortes de Alcalá de Henares el año 1348 (Madrid, Librería de los señores viudas é hijos de d. Antonio Calleja).

Aytwin AzÓCAR, Patricio (2014): El juicio arbitral, 6 $6^{a}$ edición actualizada (Santiago, LegalPublishing Chile).

Ballesteros Ríos, Manuel (1890a): La lei de organización i atribuciones de los tribunales de Chile: antecedentes, concordancia i aplicación práctica de sus disposiciones (Santiago de Chile, Imprenta Nacional), Tomo I.

Ballesteros Ríos, Manuel (1890b): La lei de organización i atribuciones de los tribunales de Chile: antecedentes, concordancia i aplicación práctica de sus disposiciones (Santiago de Chile, Imprenta Nacional), Tomo II. 
Bello, Andrés (1887): Obras completas de don Andrés Bello: proyectos de Código Civil (Santiago, impreso por Pedro G. Ramírez), Vol. XI.

Bello, Andrés (1888): Obras completas de don Andrés Bello: proyecto de Código Civil (1853) (Santiago, impreso por Pedro G. Ramírez), Vol. XII.

Bello, Andrés (1890): Obras completas de don Andrés Bello: proyecto inédito de Código Civil (Santiago, impreso por Pedro G. Ramírez), Vol. XIII.

Bello, Andrés (1981): Código Civil de la República de Chile (Caracas, La casa de Bello), Tomo II.

BıgGs, Gonzalo (2009): "Evolución y singularidad en la Institución Arbitral en Chile", en: Santelices, Velasco y Morales, Marcos (coordinadores), Estudios de derecho y propiedad intelectual. Colección de trabajos en homenaje a Arturo Alessandri Besa (Santiago, Editorial Jurídica de Chile), pp. 59-82.

Bordalí Salamanca, Andrés (2016): Derecho Jurisdiccional (Valdivia, Derecho Austral).

CaIvano, Roque (s/f): "El arbitraje: nociones introductorias", en: Revista Electrónica de Derecho Comercial. Disponible en: http://www.derechocomercial.com/Doctrina/Arb-001.pdf [visitado el 9.01.2017].

Casarino Viterbo, Mario (2006): Manual de Derecho Procesal. Derecho Procesal Orgánico, $5^{\text {a }}$ edición (Santiago, Editorial Jurídica de Chile), Tomo II.

Casarino Viterbo, Mario (1943): Códigos de la República de Chile. Código Orgánico de Tribunales (Santiago, Imprenta y Litografía Universo S.A.).

Cervantes Bravo, Graciela (2009): "El arbitraje como sistema alternativo de solución de conflictos en México", en: Revista De Jure (No 3), pp. 58-81.

Colombo Campbell, Juan (1997): Los Actos Procesales (Santiago, Editorial Jurídica de Chile), Tomo I.

Colombo Campbell, Juan (1997): Los Actos Procesales (Santiago, Editorial Jurídica de Chile), Tomo II.

Colombo Campbell, Juan (2014): "Principios Informativos del proceso Arbitral", en: Picand, Eduardo (editor), Estudios de Arbitraje en homenaje a Patricio Aylwin Azócar, 2ª edición (Santiago, LegalPublishing Chile), pp. 101-126.

Chillón Medina, José y Merino Merchán, José (1991): Tratado de arbitraje privado interno e internacional (Madrid, Civitas).

De Hevia Bolaños, Juan (1790): Curia Philipica, Nueva impresión (Madrid, Por Ramón Ruiz en la Imprenta Ulloa con las licencias necesarias), Tomo I.

De Llamas y Molina, Sancho (1852): Comentario crítico-jurídico-literal a las ochenta y tres leyes de Toro, $2^{\text {a }}$ edición (Madrid, Imprenta de la Compañía de Impresores y Libreros del Reino a cargo de D.F. Sánchez). 
Doucnac Rodríguez, Antonio (2014): "Antecedentes históricos sobre la regulación del arbitraje en Chile", en: Picand, Eduardo (editor), Estudios de Arbitraje en homenaje a Patricio Aylwin Azócar, 2 ${ }^{\mathrm{a}}$ edición (Santiago, LegalPublishing Chile), pp. 27-52.

ESCRICHE, Joaquín (1852): Diccionario razonado de legislación y jurisprudencia (Paris, Librería de Rosa, Bouret y Cía.), Tomo I.

Figueroa Yávar, Juan y Morgado San Martín, Erika (2013): Jurisdicción, competencia y disposiciones comunes a todo procedimiento (Santiago, LegalPublishing Chile).

García Pino, Gonzalo y Contreras Vásquez, Pablo (2013): "El derecho a la tutela judicial y al debido proceso en la jurisprudencia del Tribunal Constitucional chileno" en: Estudios Constitucionales (Año 11, № 2), pp. 229-280.

González EcheÑique, Javier (1954): "Los Estudios Jurídicos y la abogacía en el reino de Chile", en: Estudios de Historia del Derecho Chileno ( $\left.\mathrm{N}^{\circ} 2\right)$, pp. 1-369.

GuZMÁn BRIto, Alejandro (1979): "Para la historia de la fijación del derecho civil en Chile durante la República", en: Historia (№ 14), pp. 315-328.

GuZmán Brito, Alejandro (2005-2006): "La Enseñanza del Derecho. Historia y perspectiva" en: Anales del Instituto de Chile (Vol. XXV), pp. 273-382.

Guzmán Brito, Alejandro (1982): Andrés Bello Codificador: Historia de la fijación y codificación del derecho civil en Chile (Santiago, Ediciones de la Universidad de Chile), Tomo I.

Jequier Lehuedé, Eduardo (2011): "El arbitraje forzoso en Chile. (Un examen de constitucionalidad en el Ordenamiento Jurídico Chileno)", en: Revista Estudios Constitucionales (Año 9, No 2), pp. 453-498.

Jequier LehUedÉ, Eduardo (2013): “La acción de Inaplicabilidad por inconstitucionalidad en el derecho chileno sobre arbitraje interno: algunas propuestas", en: Revista Estudios Constitucionales (Año 11, № 2), pp. 155-200.

Jequier Lehuedé, Eduardo (2015): “Antecedentes histórico-jurídicos del arbitraje interno en Chile. Planteamiento para una revisión estructural impostergable", en: Revista lus et Praxis (Año 21, № 2), pp. 199-224.

LIRA, José Bernardo (1895): Prontuario de los Juicios o Tratado de Procedimientos Judiciales i Administrativos con arreglo a la lejislación Chilena, $5^{\text {a }}$ edición (Santiago, Librería Central de Mariano Servat), Tomo I.

LÜBbert Álvarez, Valeria (2011): "El derecho a no ser juzgado por comisiones especiales: análisis crítico de jurisprudencia", en: Revista de Estudios de la Justicia ( $\left.{ }^{\circ} 15\right)$, pp. 87-107. 
LÜBbert Álvarez, Valeria (1805): Novísima Recopilación de las leyes de España (Madrid, Imprenta de Sancha), Tomo V.

Maldonado Narváez, Marlon y Montaña Cárdenas, Luz (2017): "Arbitraje: mecanismo alternativo de solución de conflictos o privatización judicial", en: Jurídicas CUC (volumen 13, № 1), pp. 121-146.

Marín Gámez, José (2002): "Aproximación a la problemática jurídico-constitucional del arbitraje", en: Revista de Derecho Privado y Constitución ( No 16), pp. 223-257.

NúÑez Ojeda, Raúl y Pérez Ragone, Álvaro (2013): Manual de derecho procesal civil. Parte General (Santiago, LegalPublishing Chile).

Orellana Torres, Fernando (2005): Manual de derecho procesal. Derecho Procesal Orgánico (Santiago, Librotecnia), Tomo I.

Otero LATHROP, Miguel (2010): La nulidad procesal civil, penal y derecho pú-

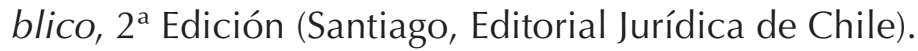

OrRego Vicuña, Francisco (2004): "El arbitraje en un nuevo sistema internacional de solución alternativa de controversias", en: Anuario Mexicano de Derecho Internacional (Vol. IV), pp. 439-456.

Orrego Vicuña (1872): Proyecto de lei de organizacion i atribuciones de los Tribunales (Santiago, Imprenta Nacional).

Orrego Vicuña (1985): Repertorio de Legislación y Jurisprudencia: Código Orgánico de Tribunales (Santiago, Editorial Jurídica de Chile).

OrRego Vicuña (1994): Revista Derecho y Jurisprudencia y Gaceta de los Tribunales (Santiago, Editorial Jurídica de Chile), Tomo XCI.

Riveros Ferrada, Carolina (2017): "Los mecanismos alternativos de solución de conflictos como manifestación de la autonomía privada en el derecho familiar chileno, a propósito de la Ley No 19.947 y 19.968", en: Revista Familia y Derecho ( $\left.{ }^{\circ} 1\right)$, pp. 119-126.

Romero Seguel, Alejandro (1999): "Nociones generales sobre justicia arbitral", en: Revista Chilena de Derecho (Vol. 26, № 2), pp. 405-430.

Romero Seguel, Alejandro y Díaz Villalobos, José Ignacio (2016): El arbitraje interno y comercial internacional (parte general), 2a edición (Santiago, Ediciones Universidad Católica de Chile).

Salas VivaldI, Julio (2013): Los incidentes y en especial el de nulidad en el proceso civil, penal y laboral, $7^{\text {a }}$ edición (Santiago, Editorial Jurídica de Chile).

San Cristóbal Reales, Susana (2013): "Sistemas alternativos de resolución de conflictos: negociación, conciliación, mediación, arbitraje, en el ámbito 
civil y mercantil", en: Anuario Jurídico y Económico Escurialense (XLVI), pp. 39-62.

Silva Bascuñán, Alejandro (2002): Tratado de derecho Constitucional (Santiago, Editorial Jurídica de Chile), Tomo VIII.

Silva Bascuñán, Alejandro (2014): "La Justicia arbitral ante la Constitución", en: Picand, Eduardo (editor), Estudios de Arbitraje en homenaje a Patricio Aylwin Azócar, 2ª edición (Santiago, Legal Publishing Chile), pp. 89-100.

Silva Cimma, Enrique (1996): Derecho Administrativo Chileno y comparado, principios fundamentales del derecho público y Estado Solidario (Santiago, Editorial Jurídica de Chile).

De Tapia, Eugenio (1828): Febrero Novisimo, ó Librería de los Jueces, Abogados y Escribanos (Valencia, imprenta de Ildelfonso Mompié), Tomo IV.

Vargas Fontecilla, Francisco (1864): Proyecto de Lei de Organización i Atribuciones de los Tribunales (Santiago de Chile, Imprenta Nacional).

VÁsquez Palma, María Fernanda (2010): “Comprensión del principio 'competencia-competencia' y configuración de la nulidad o ineficacia del acuerdo arbitral", en: Revista Chilena de Derecho Privado (No 15), pp. 181-196.

VÁsquez Palma, María Fernanda (2014): "La autonomía de la voluntad en el instituto arbitral chileno: entre su reconocimiento, su imprecisión y negación", en: Picand, Eduardo (editor), Estudios de Arbitraje en homenaje a Patricio Aylwin Azócar, 2a edición (Santiago, LegalPublishing Chile), pp. 241-261. VÁsquez Palma, María Fernanda (2018): Tratado de Arbitraje en Chile. Arbitraje interno e internacional (Santiago, LegalPublishing Chile).

YAURí AMARO, León (2013): "El Convenio arbitral", en: Vlex Internacional (№ 17). Disponible en: https://app.vlex.com/\#/vid/convenio-arbitral-452287817 [visitado el 09/01/2017].

\section{NORMAS JURÍDICAS CITADAS}

Código Orgánico de Tribunales (Chile).

\section{JURISPRUDENCIA CITADA}

Martín con Ulloa (2014): Corte de Apelaciones de Concepción 30 de junio de 2014 (acción de protección) en: MJ 32276.

Felizando Sánchez Oyarzo (2013): Corte de Apelaciones de Punta Arenas 25 de octubre de 2015 (recurso casación en la forma) en: MJ 36333. 
